\title{
Impact of water table level on annual carbon and greenhouse gas balances of a restored peat extraction area
}

\author{
Järvi Järveoja ${ }^{1}$, Matthias Peichl ${ }^{2}$, Martin Maddison ${ }^{1}$, Kaido Soosaar ${ }^{1}$, Kai Vellak ${ }^{3}$, Edgar Karofeld ${ }^{3}$, Alar Teemusk ${ }^{1}$, \\ and Ülo Mander ${ }^{1,4}$ \\ ${ }^{1}$ Department of Geography, Institute of Ecology and Earth Sciences, University of Tartu, Tartu, Estonia \\ ${ }^{2}$ Department of Forest Ecology and Management, Swedish University of Agricultural Sciences, Umeå, Sweden \\ ${ }^{3}$ Department of Botany, Institute of Ecology and Earth Sciences, University of Tartu, Tartu, Estonia \\ ${ }^{4}$ Hydrosystems and Bioprocesses Research Unit, National Research Institute of Science and Technology \\ for Environment and Agriculture (IRSTEA), Antony, France \\ Correspondence to: Järvi Järveoja (jarvi.jarveoja@ut.ee)
}

Received: 9 September 2015 - Published in Biogeosciences Discuss.: 27 October 2015

Revised: 23 February 2016 - Accepted: 12 April 2016 - Published: 4 May 2016

\begin{abstract}
Peatland restoration may provide a potential afteruse option to mitigate the negative climate impact of abandoned peat extraction areas; currently, however, knowledge about restoration effects on the annual balances of carbon (C) and greenhouse gas (GHG) exchanges is still limited. The aim of this study was to investigate the impact of contrasting mean water table levels (WTLs) on the annual C and GHG balances of restoration treatments with high $\left(\operatorname{Res}_{\mathrm{H}}\right)$ and low $\left(\operatorname{Res}_{\mathrm{L}}\right)$ WTL relative to an unrestored bare peat (BP) site. Measurements of carbon dioxide $\left(\mathrm{CO}_{2}\right)$, methane $\left(\mathrm{CH}_{4}\right)$ and nitrous oxide $\left(\mathrm{N}_{2} \mathrm{O}\right)$ fluxes were conducted over a full year using the closed chamber method and complemented by measurements of abiotic controls and vegetation cover. Three years following restoration, the difference in the mean WTL resulted in higher bryophyte and lower vascular plant cover in $\operatorname{Res}_{\mathrm{H}}$ relative to $\mathrm{Res}_{\mathrm{L}}$. Consequently, greater gross primary production and autotrophic respiration associated with greater vascular plant cover were observed in $\operatorname{Res}_{\mathrm{L}}$ compared to $\operatorname{Res}_{\mathrm{H}}$. However, the means of the measured net ecosystem $\mathrm{CO}_{2}$ exchanges (NEE) were not significantly different between $\operatorname{Res}_{\mathrm{H}}$ and $\mathrm{Res}_{\mathrm{L}}$. Similarly, no significant differences were observed in the respective means of $\mathrm{CH}_{4}$ and $\mathrm{N}_{2} \mathrm{O}$ exchanges. In comparison to the two restored sites, greater net $\mathrm{CO}_{2}$, similar $\mathrm{CH}_{4}$ and greater $\mathrm{N}_{2} \mathrm{O}$ emissions occurred in $\mathrm{BP}$. On the annual scale, $\operatorname{Res}_{\mathrm{H}}$, Res $\mathrm{R}_{\mathrm{L}}$ and BP were C sources of 111,103 and $268 \mathrm{~g} \mathrm{C} \mathrm{m}^{-2} \mathrm{yr}^{-1}$ and had positive GHG balances of $4.1,3.8$ and $10.2 \mathrm{tCO}_{2} \mathrm{eq} \mathrm{ha}^{-1} \mathrm{yr}^{-1}$, respectively. Thus, the different WTLs had a limited impact on the $\mathrm{C}$ and
\end{abstract}

GHG balances in the two restored treatments 3 years following restoration. However, the C and GHG balances in $\mathrm{Res}_{\mathrm{H}}$ and $\operatorname{Res}_{\mathrm{L}}$ were considerably lower than in $\mathrm{BP}$ due to the large reduction in $\mathrm{CO}_{2}$ emissions. This study therefore suggests that restoration may serve as an effective method to mitigate the negative climate impacts of abandoned peat extraction areas.

\section{Introduction}

Peatlands are widely distributed across the Northern Hemisphere covering 5-30\% of national land areas in northern Europe, North America and Russia and play a key role in the global carbon (C) cycle (Gorham, 1991; Joosten and Clarke, 2002; Vasander et al., 2003; Charman et al., 2013). Throughout the Holocene, northern peatlands have accumulated $\sim 270-450 \mathrm{GtC}$ as peat and presently store about a third of the global soil C pool (Gorham, 1991; Turunen et al., 2002). They also provide a small but persistent long-term $\mathrm{C}$ sink (between 20 and $30 \mathrm{~g} \mathrm{C} \mathrm{m}^{-2} \mathrm{yr}^{-1}$ ) (Gorham, 1991; Vitt et al., 2000; Roulet et al., 2007; Nilsson et al., 2008). Carbon accumulation in peatland ecosystems occurs mainly due to the slow decomposition rate under the anoxic conditions caused by high water table levels (WTLs) (Clymo, 1983). Within the past century, however, a large fraction of peatlands has been exploited for energy production and horticultural use. Since commercial peat extraction requires 
initial vegetation removal and drainage, harvested peatlands are turned into $\mathrm{C}$ sources by eliminating the carbon dioxide $\left(\mathrm{CO}_{2}\right)$ uptake during plant photosynthesis and increasing $\mathrm{CO}_{2}$ emission due to enhanced aerobic decomposition of organic matter. Thus, following the cessation of peat extraction activities, after-use alternatives that mitigate the negative climate impacts of these degraded and abandoned areas are required.

Among different after-use alternatives, re-establishment of peatland vegetation, which is essential for returning the extracted peatlands back into functional peat-accumulating ecosystems, has been shown to provide climate benefits (Tuittila et al., 1999, 2000a; Graf and Rochefort, 2009; Waddington et al., 2010; Strack and Zuback, 2013) as well as high ecological value (Rochefort and Lode, 2006; Lamers et al., 2015). However, due to the harsh environmental conditions of bare peat surfaces and the lack of a propagule bank, spontaneous regeneration of self-sustaining ecosystems rarely occurs and thus human intervention is necessary to initiate this process. For instance, active reintroduction of natural peatland vegetation communities (i.e., primarily fragments of Sphagnum mosses and companion species) combined with rewetting has been shown to be an effective method to initiate the recovery of Sphagnumdominated ecosystems with resumed long-term peat accumulation (Quinty and Rochefort, 2003).

Re-establishing peatland vegetation and raising the WTL both affect the ecosystem $\mathrm{C}$ balance and peat accumulation through their impact on the production and decomposition of organic matter. Specifically, vegetation development results in increased plant photosynthesis and respiration (i.e., autotrophic respiration) as well as in greater substrate supply for methanogenesis. In addition, restoring the hydrological regime affects the $\mathrm{CO}_{2}$ uptake by vegetation and the microbial decomposition of organic matter (i.e., heterotrophic respiration) by increasing water availability and decreasing soil oxygen status of the upper peat layer. Moreover, an increase in the WTL also reduces the depth of the aerobic peat layer in which methane $\left(\mathrm{CH}_{4}\right)$ oxidation may occur. As a consequence, a higher WTL following the filling or blocking of the drainage ditches commonly results in decreased $\mathrm{CO}_{2}$ emissions (Tuittila et al., 1999; Waddington and Warner, 2001) and increased emissions of $\mathrm{CH}_{4}$ (Tuittila et al., 2000a; Waddington and Day, 2007; Vanselow-Algan et al., 2015) relative to the abandoned bare peat area. The depth of the WTL is therefore, in addition to the vegetation biomass recovery, a key controlling variable of the ecosystem $\mathrm{CO}_{2}$ and $\mathrm{CH}_{4}$ exchanges following peatland restoration.

Considering the strong effects of the WTL on plant succession and ecosystem $\mathrm{C}$ exchanges, differences in the depth of the re-established WTL baseline (i.e., the mean WTL) due to the varying effectiveness of initial restoration activities (e.g., ditch blocking, surface peat stripping) may have implications for the trajectories of vegetation development and recovery of the $\mathrm{C}$ sink function following restoration. To date, only a few studies (e.g., Tuittila et al., 1999, 2004) have investigated the impact of contrasting WTLs on the subsequent ecosystem $\mathrm{C}$ balance within the same restoration site. Understanding the sensitivity of the $\mathrm{C}$ balance to differences in the reestablished WTL baseline is, however, imperative when evaluating the potential of restoration for mitigating the negative climate impacts of drained peatlands. Moreover, estimates of the $\mathrm{C}$ sink-source strength of restored and unrestored peatlands have been limited to the growing season period in most previous studies (Tuittila et al., 1999, 2000a, 2004; Waddington et al., 2010; Samaritani et al., 2011; Strack et al., 2014). In contrast, data on annual budgets, which are required to evaluate the full climate benefits of peatland restoration relative to the abandoned peat extraction area, are currently scarce and to our knowledge only reported in a few studies (e.g., Yli-Petäys et al., 2007; Strack and Zuback, 2013).

Furthermore, the full ecosystem greenhouse gas (GHG) balance also includes emissions of nitrous oxide $\left(\mathrm{N}_{2} \mathrm{O}\right)$, a greenhouse gas with an almost 300 times stronger warming effect relative to $\mathrm{CO}_{2}$ (IPCC, 2013). Highly variable $\mathrm{N}_{2} \mathrm{O}$ emissions ranging from $<0.06$ to $26 \mathrm{~kg} \mathrm{~N} \mathrm{ha}^{-1} \mathrm{yr}^{-1}$ have been previously reported for drained organic soils, with the highest emissions occurring from mesic and nutrient-rich sites (Martikainen et al., 1993; Regina et al., 1996; Maljanen et al., 2010). In contrast, $\mathrm{N}_{2} \mathrm{O}$ emissions are generally low in natural peatlands because environmental conditions (i.e., uptake of mineral $\mathrm{N}$ by the vegetation and anaerobic conditions due to high WTL favoring the complete reduction of $\mathrm{N}_{2} \mathrm{O}$ to dinitrogen) diminish the potential for $\mathrm{N}_{2} \mathrm{O}$ production (Martikainen et al., 1993; Regina et al., 1996; Silvan et al., 2005; Roobroeck et al., 2010). Thus, while the focus of most previous studies in restored peatlands has been limited to the $\mathrm{CO}_{2}$ and $\mathrm{CH}_{4}$ exchanges, accounting for $\mathrm{N}_{2} \mathrm{O}$ emissions might be imperative when assessing the climate benefits of peatland restoration as an after-use option for abandoned peat extraction areas. To our knowledge, however, $\mathrm{N}_{2} \mathrm{O}$ fluxes in restored peatlands have not been quantified to date.

This study investigated the GHG fluxes (i.e., $\mathrm{CO}_{2}, \mathrm{CH}_{4}$ and $\mathrm{N}_{2} \mathrm{O}$ ) and their biotic and abiotic controls in a restored peat extraction area with high $\left(\operatorname{Res}_{\mathrm{H}}\right)$ and low $\left(\operatorname{Res}_{\mathrm{L}}\right)$ WTLs and in an unrestored bare peat (BP) site. The two main objectives were (i) to investigate the impact of contrasting mean WTLs on the annual C and GHG balances of a restored peatland and (ii) to assess the potential of peatland restoration for mitigating the $\mathrm{C}$ and $\mathrm{GHG}$ emissions from abandoned peat extraction areas. Our hypotheses were that (i) the $\mathrm{C}$ and GHG balances are improved in $\operatorname{Res}_{\mathrm{H}}$ relative to $\mathrm{Res}_{\mathrm{L}}$ since the increased net $\mathrm{CO}_{2}$ uptake, as a result of reduced peat mineralization and greater water availability enhancing gross primary production (GPP), outweighs the increase in $\mathrm{CH}_{4}$ emissions; and (ii) the $\mathrm{C}$ and GHG balances of the two restoration treatments are ameliorated relative to $\mathrm{BP}$ due to the decreased $\mathrm{CO}_{2}$ emissions from peat mineralization and lower $\mathrm{N}_{2} \mathrm{O}$ emissions under more anoxic conditions following rewetting of drained peatlands. 


\section{Material and methods}

\subsection{Experimental area}

The study was conducted in the Tässi peat extraction area located in central Estonia $\left(58^{\circ} 32^{\prime} 16^{\prime \prime} \mathrm{N}, 25^{\circ} 51^{\prime} 43^{\prime \prime} \mathrm{E}\right)$. The region has a temperate climate with long-term mean (19812010) annual temperature and precipitation of $5.8^{\circ} \mathrm{C}$ and $764 \mathrm{~mm}$, respectively (Estonian Weather Service). Peat extraction in the peatland started in late 1960s and today peat continues to be harvested for horticultural purposes using the milling technique on about 264 ha.

The current study was carried out on a 4.5 ha area which was set aside from peat extraction in the early 1980s. The residual Sphagnum peat layer depth is about $2.5 \mathrm{~m}$. A section approximately 0.24 ha in size within the abandoned site was restored in April 2012. The restoration was done following a slightly modified protocol of the moss layer transfer technique (Quinty and Rochefort, 2003) aimed at restoring the growth of Sphagnum mosses and initiating the development of a natural bog community. The first restoration steps included stripping the uppermost oxidized peat layer $(20 \mathrm{~cm})$ and flattening the freshly exposed surface. In addition, the peat along the borders of the restoration area was compressed and the outflow drainage ditch was dammed with peat material to reduce the lateral water outflow from the experimental site.

To study the impact of WTL on restoration success in terms of vegetation development and GHG fluxes, the restoration site was divided into wetter and drier sections by lowering the peat surface by $10 \mathrm{~cm}$ for approximately onethird of the area. This resulted in restoration treatments with high and low WTLs (i.e., $\operatorname{Res}_{\mathrm{H}}$ and $\mathrm{Res}_{\mathrm{L}}$ ). In addition, an unrestored BP site was included in the study as a reference. Two replicate plots $(20 \times 20 \mathrm{~m})$ were established for each of the three treatments.

To enhance vegetation succession, living plant fragments from Sphagnum-dominated hummocks were collected from a nearby $(10 \mathrm{~km})$ donor site (Soosaare bog) and spread out in the ratio of $1: 10$ (i.e., $1 \mathrm{~m}^{2}$ of collected plant fragments were spread over $10 \mathrm{~m}^{2}$ ) in the $\mathrm{Res}_{\mathrm{H}}$ and $\operatorname{Res}_{\mathrm{L}}$ treatments. As the last step, straw mulch was applied to protect plant fragments from solar radiation and to improve moisture conditions. Further details about the restoration procedure at this study site have been given in Karofeld et al. (2015).

Three years following restoration, the bryophyte species found at the restored site were dominated primarily by Sphagnum mosses (e.g., S. fuscum, S. rubellum and S. magellanicum). The common vascular plant species observed post-restoration included shrubs and trees such as common heather (Calluna vulgaris L.), common cranberry (Oxycoccus palustris Pers.), downy birch (Betula pubescens Ehrh.), bog rosemary (Andromeda polifolia L.) and Scots pine (Pinus sylvestris L.), with a minor cover of accompanying herbaceous sedge and forb species such as tussock cotton- grass (Eriophorum vaginatum L.) and round-leaved sundew (Drosera rotundifolia L.) (Karofeld et al., 2015).

\subsection{Environmental measurements}

A meteorological station to continuously monitor environmental variables was set up on-site in June 2014. This included measurements of air temperature $\left(T_{\mathrm{a}}\right.$; model CS 107 , Campbell Scientific Inc., Logan, UT, USA), photosynthetically active radiation (PAR; model LI-190SL, LI-COR Inc., Lincoln, NE, USA) and precipitation (PPT; tipping bucket model 52202, R. M. Young Company, Traverse City, MI, USA) at $1.2 \mathrm{~m}$ height above the ground. Soil temperature ( $T_{\mathrm{s}}$; depths of 5 and $30 \mathrm{~cm}$ ) was measured with temperature probes (model CS 107, Campbell Scientific Inc., Logan, UT, USA) and soil volumetric water content (VWC; depth $5 \mathrm{~cm}$ ) with water content reflectometers (model CS615, Campbell Scientific Inc., Logan, UT, USA). All automated abiotic data were collected in $1 \mathrm{~min}$ intervals and stored as $10 \mathrm{~min}$ averages on a data logger (CR1000, Campbell Scientific Inc., Logan, UT, USA). In addition, continuous $30 \mathrm{~min}$ records of the WTL relative to the soil surface were obtained with submerged water level loggers (HOBO, Onset Computer Corporation, Bourne, MA, USA) placed inside perforated $1.0 \mathrm{~m}$ long PVC pipes $(\varnothing 5 \mathrm{~cm}$; sealed in the lower end).

The on-site meteorological measurements were complemented by Estonian Weather Service data to obtain complete time series of $T_{\mathrm{a}}$, PPT and PAR over the entire year. Hourly means of $T_{\mathrm{a}}$ and daily sums of PPT were obtained from the closest ( $\sim 20 \mathrm{~km}$ away) Viljandi meteorological station. Global radiation (hourly sums) data from the Tartu meteorological station ( $\sim 40 \mathrm{~km}$ away) were converted to PAR based on a linear correlation relationship to on-site PAR.

In addition, manual measurements of $T_{\mathrm{S}}$ (depths 10, 20, 30 and $40 \mathrm{~cm}$ ) were recorded by a handheld temperature $\log$ ger (Comet Systems Ltd., Rožnov pod Radhoštěm, Czech Republic) and VWC (depth $0-5 \mathrm{~cm}$ ) using a handheld soil moisture sensor (model GS3, Decagon Devices Inc., Pullman, WA, USA) during each sampling campaign. Furthermore, groundwater temperature, $\mathrm{pH}$, redox potential, dissolved oxygen content, electrical conductivity as well as ammonium and nitrate concentrations were measured in observation wells $(\varnothing 7.5 \mathrm{~cm}, 1.0 \mathrm{~m}$ long PVC pipes perforated and sealed in the lower end) installed at each sampling location using YSI Professional Plus handheld instruments (YSI Inc., Yellow Springs, OH, USA). In addition, soil samples (depth $0-10 \mathrm{~cm}$ ) in three replicates were taken from each of the treatments and analyzed for $\mathrm{pH}$ as well as total $\mathrm{C}$, total $\mathrm{N}$, $\mathrm{P}, \mathrm{K}, \mathrm{Ca}$ and $\mathrm{S}$ contents at the Tartu Laboratory of the Estonian Environmental Research Centre. Three additional samples were taken from the same depth to determine bulk density in each treatment. Mean values for these soil properties are summarized in Table 1. 
Table 1. Soil properties in restoration treatments with high $\left(\operatorname{Res}_{\mathrm{H}}\right)$ and low $\left(\operatorname{Res}_{\mathrm{L}}\right)$ water table level and bare peat (BP); numbers in parenthesis indicate standard error.

\begin{tabular}{llll}
\hline Soil property & $\operatorname{Res}_{\mathrm{H}}$ & $\operatorname{Res}_{\mathrm{L}}$ & $\mathrm{BP}$ \\
\hline $\mathrm{pH}$ & $4.0(0.07)$ & $3.9(0.07)$ & $3.9(0.06)$ \\
Bulk density $\left(\mathrm{g} \mathrm{cm}^{-3}\right)$ & $0.08(0.002)$ & $0.09(0.003)$ & $0.13(0.004)$ \\
$\mathrm{C}(\%)$ & $49(0.6)$ & $50(0.3)$ & $48(0.6)$ \\
$\mathrm{N}(\%)$ & $0.61(0.04)$ & $0.76(0.05)$ & $0.85(0.04)$ \\
$\mathrm{C} / \mathrm{N}$ & 80.3 & 65.8 & 56.5 \\
$\mathrm{P}\left(\mathrm{mg} \mathrm{g}^{-1}\right)$ & $0.2(0.03)$ & $0.2(0.02)$ & $0.4(0.03)$ \\
$\mathrm{K}\left(\mathrm{mg} \mathrm{g}^{-1}\right)$ & $0.2(0.007)$ & $0.2(0.003)$ & $0.1(0.004)$ \\
$\mathrm{Ca}\left(\mathrm{mg} \mathrm{g}^{-1}\right)$ & $2.1(0.07)$ & $2.1(0.07)$ & $3.4(0.23)$ \\
$\mathrm{S}\left(\mathrm{mg} \mathrm{g}^{-1}\right)$ & $0.9(0.12)$ & $1.0(0.05)$ & $1.4(0.09)$ \\
\hline
\end{tabular}

\subsection{Vegetation cover estimation}

To assess the effect of vegetation development on GHG fluxes, vegetation cover (\%) and species composition were recorded inside each of the flux measurement collars (see Sect. 2.4) in late spring. In each collar, the cover was estimated visually for each species and rounded to the nearest $1 \%$. Bryophyte, vascular plant and total vegetation cover were computed as the sum of their respective individual species coverages.

\subsection{Net ecosystem $\mathrm{CO}_{2}$ exchange (NEE), ecosystem respiration $\left(\boldsymbol{R}_{\mathrm{e}}\right)$, GPP and net primary production (NPP) measurements}

To evaluate the impact of WTL on NEE in the restored $\mathrm{Res}_{\mathrm{H}}$ and $\operatorname{Res}_{\mathrm{L}}$ treatments, $\mathrm{CO}_{2}$ flux measurements were conducted biweekly from May to December 2014 at three sampling locations within each replicate plot (i.e., six locations per treatment) using the closed dynamic chamber method. At each sampling location, a collar $(\varnothing 50 \mathrm{~cm})$ with a water-filled ring for air-tight sealing was permanently installed to a soil depth of $10 \mathrm{~cm}$. NEE measurements were conducted in random plot order (to avoid diurnal effects) using a clear Plexiglas chamber ( $95 \%$ transparency; h $50 \mathrm{~cm}, \mathrm{~V} 65 \mathrm{~L}$ ) combined with a portable infrared gas analyzer (IRGA; EGM-4, PP Systems, Hitchin, UK). The chamber was equipped with a sensor to measure PAR and $T_{\mathrm{a}}$ (TRP-2, PP Systems, Hitchin, UK) inside the chamber. Ambient $T_{\mathrm{a}}$ was also recorded with an additional temperature sensor placed on the outside of the chamber. Cooling packs placed inside the chamber were used to avoid a temperature increase inside the chamber during measurements. The chamber was also equipped with a lowspeed fan to ensure constant air circulation. After every NEE measurement, $R_{\mathrm{e}}$ was determined from a subsequent measurement during which the transparent chamber was covered with an opaque and light reflective shroud. $\mathrm{CO}_{2}$ concentrations, PAR, $T_{\mathrm{a}}$, pressure and relative humidity were recorded by the IRGA system every $4.8 \mathrm{~s}$ over a 4 or $3 \mathrm{~min}$ chamber deployment period for NEE and $R_{\mathrm{e}}$ measurements, respec- tively. Since the aim of this study was to assess the atmospheric impact of restoration, all fluxes are expressed following the atmospheric sign convention in which positive and negative fluxes represent emission to and uptake from the atmosphere, respectively.

GPP was derived from the difference between NEE and $R_{\mathrm{e}}$ (i.e., GPP $=\mathrm{NEE}-R_{\mathrm{e}}$ ). In addition, an estimate of NPP was derived from the difference between NEE and heterotrophic respiration $\left(R_{\mathrm{h}}\right.$; see Sect. 2.5) (i.e., $\left.\mathrm{NPP}=\mathrm{NEE}-R_{\mathrm{h}}\right)$.

$R_{\mathrm{e}}$ estimates during the non-growing-season months of March to April 2014 and January to February 2015 were determined by closed static chamber measurements (described in Sect. 2.6). Air samples collected during these measurements were analyzed for their $\mathrm{CO}_{2}$ concentrations on a Shimadzu GC-2014 gas chromatograph with an electron capture detector. These $R_{\mathrm{e}}$ estimates also represented non-growingseason NEE for all treatments.

In the BP treatment, $R_{\mathrm{e}}$ was determined by measurements using a separate closed dynamic chamber setup as described below in Sect. 2.5. Due to the absence of vegetation, GPP as well as NPP were assumed to be 0 and NEE subsequently equaled $R_{\mathrm{e}}$ in the BP treatment.

\subsection{Heterotrophic and autotrophic respiration measurements}

From May to December 2014, $R_{\mathrm{h}}$ was measured simultaneously with NEE from separate PVC collars $(\varnothing 17.5 \mathrm{~cm})$ inserted to a depth of $10 \mathrm{~cm}$ beside each NEE collar. The soil around the $R_{\mathrm{h}}$ collars was cut with a sharp knife to a depth of $30 \mathrm{~cm}$ in April 2014 to exclude respiration from the roots. The area inside the collars was cleared of living moss and vascular plants and kept free of vegetation during the remaining year. For $R_{\mathrm{h}}$ measurements, a second set of instrumentation was used which included an opaque chamber (h $30 \mathrm{~cm}$, V $0.065 \mathrm{~L}$; equipped with a low-speed fan) combined with an EGM-4 infrared gas analyzer. During each $R_{\mathrm{h}}$ measurement, $\mathrm{CO}_{2}$ concentration and $T_{\mathrm{a}}$ inside the chamber were recorded every $4.8 \mathrm{~s}$ over a period of $3 \mathrm{~min}$. Autotrophic respiration $\left(R_{\mathrm{a}}\right)$ was derived from the difference between the measured $R_{\mathrm{e}}$ and $R_{\mathrm{h}}$ fluxes (i.e., $R_{\mathrm{a}}=R_{\mathrm{e}}-R_{\mathrm{h}}$ ). Due to the absence of vegetation, $R_{\mathrm{a}}$ was not determined in BP.

\subsection{Methane and nitrous oxide flux measurements}

To assess the impact of WTL on $\mathrm{CH}_{4}$ and $\mathrm{N}_{2} \mathrm{O}$ exchanges, flux measurements were conducted with the closed static chamber method at a biweekly to monthly interval from March 2014 to February 2015 at the same locations (i.e., same collars) as were used for the NEE measurements (described in Sect. 2.4). During each chamber deployment period, a series of air samples were drawn from the chamber headspace (h $50 \mathrm{~cm}, \mathrm{~V} 65 \mathrm{~L}$; white opaque PVC chambers) into pre-evacuated $(0.3 \mathrm{mbar}) 50 \mathrm{~mL}$ glass bottles 0 , $0.33,0.66$ and $1 \mathrm{~h}$ after closing the chamber. The air sam- 
ples were analyzed for $\mathrm{CH}_{4}$ and $\mathrm{N}_{2} \mathrm{O}$ concentrations with a flame ionization detector and an electron capture detector, respectively, using a Shimadzu GC-2014 gas chromatograph combined with a Loftfield automatic sample injection system (Loftfield et al., 1997).

\subsection{Flux calculation}

Fluxes of $\mathrm{CO}_{2}, \mathrm{CH}_{4}$ and $\mathrm{N}_{2} \mathrm{O}$ were calculated from the linear change in gas concentration in the chamber headspace over time, adjusted by the ground area enclosed by the collar, volume of chamber headspace, air density and molar mass of gas at measured chamber $T_{\mathrm{a}}$. The linear slope in case of the dynamic chamber measurements was calculated for a window of 25 measurement points (i.e., $2 \mathrm{~min}$ ) moving stepwise (with one-point increments) over the entire measurement period after discarding the first two measurement points (i.e., applying a $9.6 \mathrm{~s}$ "dead band"). The slope of the window with the best coefficient of determination $\left(R^{2}\right)$ was selected as the final slope for each measurement. In the static chamber method, the linear slope was calculated over the four available concentration values.

All dynamic chamber $\mathrm{CO}_{2}$ fluxes with a $R^{2} \geq 0.90$ $(p<0.001)$ were accepted as good fluxes. However, since small fluxes generally result in a lower $R^{2}$ (which is especially critical for NEE measurements), dynamic chamber fluxes with an absolute slope within $\pm 0.03 \mathrm{ppm} \mathrm{s}^{-1}$ were always accepted. The slope threshold was determined based on a regression relationship between the slope and respective $R^{2}$ values. For static chamber measurements, the $R^{2}$ threshold for accepting $\mathrm{CO}_{2}, \mathrm{CH}_{4}$ and $\mathrm{N}_{2} \mathrm{O}$ fluxes was $0.90(p<0.05)$, $0.80(p<0.1)$ and $0.80(p<0.1)$, respectively, except when the maximum difference among the four concentration values was less than the gas-specific $\mathrm{GC}$ detection limit (i.e., $<20 \mathrm{ppm}$ for $\mathrm{CO}_{2},<20 \mathrm{ppb}$ for $\mathrm{CH}_{4}$ and $<20 \mathrm{ppb}$ for $\mathrm{N}_{2} \mathrm{O}$ ), in which case no filtering criterion was used. Based on these quality criteria $11 \%$ of NEE, $9 \%$ of $R_{\mathrm{e}}, 21 \%$ of $R_{\mathrm{h}}, 33 \%$ of $\mathrm{CH}_{4}$ and $6 \%$ of $\mathrm{N}_{2} \mathrm{O}$ fluxes were discarded from subsequent data analysis.

\subsection{Annual balances}

To obtain estimates for the annual $\mathrm{CO}_{2}$ fluxes, nonlinear regression models were developed based on the measured $\mathrm{CO}_{2}$ flux, PAR, WTL and $T_{\mathrm{a}}$ data following Tuittila et al. (2004). As a first step, measured GPP fluxes were fitted to PAR inside the chamber using a hyperbolic function adjusted by a second term which accounted for additional WTL effects (Eq. 1):

$\mathrm{GPP}=\frac{\alpha \times A_{\max } \times \mathrm{PAR}}{\alpha \times \mathrm{PAR}+A_{\max }} \times \exp \left[-0.5 \times\left(\frac{\mathrm{WTL}-\mathrm{WTL}_{\mathrm{opt}}}{\mathrm{WTL}_{\mathrm{tol}}}\right)^{2}\right]$,

where GPP is the gross primary production $\left(\mathrm{mg} \mathrm{C} \mathrm{m}^{-2} \mathrm{~h}^{-1}\right)$, PAR is the photosynthetically active radiation $\left(\mu \mathrm{mol} \mathrm{m} \mathrm{m}^{-2} \mathrm{~s}^{-1}\right), \alpha$ is the light use efficiency of photosynthesis (i.e., the initial slope of the light response curve;
Table 2. Parameters for the gross primary production (GPP) and ecosystem respiration $\left(R_{\mathrm{e}}\right)$ models in restoration treatments with high $\left(\operatorname{Res}_{\mathrm{H}}\right)$ and low $\left(\operatorname{Res}_{\mathrm{L}}\right)$ water table level (WTL) and bare peat (BP): $\alpha$ is the quantum use efficiency of photosynthesis ( $\mathrm{mgC} \mu$ mol photon $\left.^{-1}\right) ; A_{\max }$ is the maximum rate of photosynthesis at light saturation $\left(\mathrm{mg} \mathrm{C} \mathrm{m}^{-2} \mathrm{~h}^{-1}\right)$; WTL opt is the WTL at which maximum photosynthetic activity occurs; $\mathrm{WTL}_{\text {tol }}$ is the tolerance, i.e., the width of the Gaussian response curve of GPP to WTL; $R_{0}$ is the respiration $\left(\mathrm{mg} \mathrm{C} \mathrm{m}^{-2} \mathrm{~h}^{-1}\right)$ at $0{ }^{\circ} \mathrm{C} ; b$ is the sensitivity of respiration to air temperature; numbers in parenthesis indicate standard error; Adj. $R^{2}$ is the adjusted $R^{2}$.

\begin{tabular}{llll}
\hline Model parameter & $\operatorname{Res}_{\mathrm{H}}$ & $\operatorname{Res}_{\mathrm{L}}$ & $\mathrm{BP}$ \\
\hline GPP model & & & \\
$\alpha$ & $-0.20(0.07)$ & $-0.23(0.07)$ & $\mathrm{n} / \mathrm{a}$ \\
$A_{\mathrm{max}}$ & $-98.0(39.9)$ & $-121.9(43.4)$ & $\mathrm{n} / \mathrm{a}$ \\
WTL $_{\mathrm{opt}}$ & $-18.7(8.4)$ & $-24.9(6.4)$ & $\mathrm{n} / \mathrm{a}$ \\
WTL $_{\text {tol }}$ & $16.4(10.0)$ & $21.0(9.7)$ & $\mathrm{n} / \mathrm{a}$ \\
Adj. $R^{2}$ & 0.58 & 0.61 & $\mathrm{n} / \mathrm{a}$ \\
$R_{\mathrm{e}}$ model & & & \\
$R_{0}$ & $13.0(1.5)$ & $13.4(1.5)$ & $18.6(2.7)$ \\
$b$ & $0.056(0.005)$ & $0.064(0.005)$ & $0.055(0.005)$ \\
Adj. $R^{2}$ & 0.62 & 0.71 & 0.60 \\
\hline
\end{tabular}

$\mathrm{n} / \mathrm{a}$ is not applicable

$\operatorname{mg~C} \mu$ mol photon $\left.{ }^{-1}\right), A_{\max }$ is the maximum photosynthesis at light saturation $\left(\mathrm{mg} \mathrm{C} \mathrm{m}^{-2} \mathrm{~h}^{-1}\right)$, WTL is the water table level $(\mathrm{cm}), \mathrm{WTL}_{\mathrm{opt}}$ is the WTL at which maximum photosynthetic activity occurs and $\mathrm{WTL}_{\mathrm{tol}}$ is the tolerance (i.e., the width of the Gaussian response curve of GPP to WTL).

Secondly, $R_{\mathrm{e}}$ fluxes were fitted to $T_{\mathrm{a}}$ using an exponential function (Eq. 2):

$R_{\mathrm{e}}=R_{0} \times \exp ^{\left(b \times T_{\mathrm{a}}\right)}$,

where $R_{\mathrm{e}}$ is the ecosystem respiration $\left(\mathrm{mg} \mathrm{C} \mathrm{m}^{-2} \mathrm{~h}^{-1}\right)$, $T_{\mathrm{a}}$ is the air temperature $\left({ }^{\circ} \mathrm{C}\right), R_{0}$ is the respiration $\left(\mathrm{mg} \mathrm{C} \mathrm{m}{ }^{-2} \mathrm{~h}^{-1}\right)$ at $0^{\circ} \mathrm{C}$ and $b$ is the sensitivity of respiration to $T_{\mathrm{a}}$. Both GPP and $R_{\mathrm{e}}$ were modeled with hourly resolution using hourly PAR, WTL and $T_{\mathrm{a}}$ as input variables. Growing season (1 May to October 31) GPP and annual $R_{\mathrm{e}}$ were then derived from the cumulative sums of these modeled fluxes. The balance between growing season GPP and annual $R_{\mathrm{e}}$ estimates resulted in the annual NEE in $\mathrm{Res}_{\mathrm{H}}$ and $\operatorname{Res}_{\mathrm{L}}$, whereas annual $R_{\mathrm{e}}$ represented annual NEE in BP. The GPP and $R_{\mathrm{e}}$ model parameters for the different treatments are summarized in Table 2.

Annual sums of $\mathrm{CH}_{4}$ and $\mathrm{N}_{2} \mathrm{O}$ fluxes were estimated by scaling their hourly mean and median flux values, respectively, to annual sums. The median flux was used for $\mathrm{N}_{2} \mathrm{O}$ to avoid a positive bias caused by episodic high peak fluxes measured directly after rainfall events. The annual sums were converted to $\mathrm{CO}_{2}$ equivalents $\left(\mathrm{CO}_{2}\right.$ eq) using the global warming potentials (over a 100-year time frame including carbon-climate feedbacks) of 34 and 298 for $\mathrm{CH}_{4}$ and $\mathrm{N}_{2} \mathrm{O}$, respectively (IPCC, 2013). 


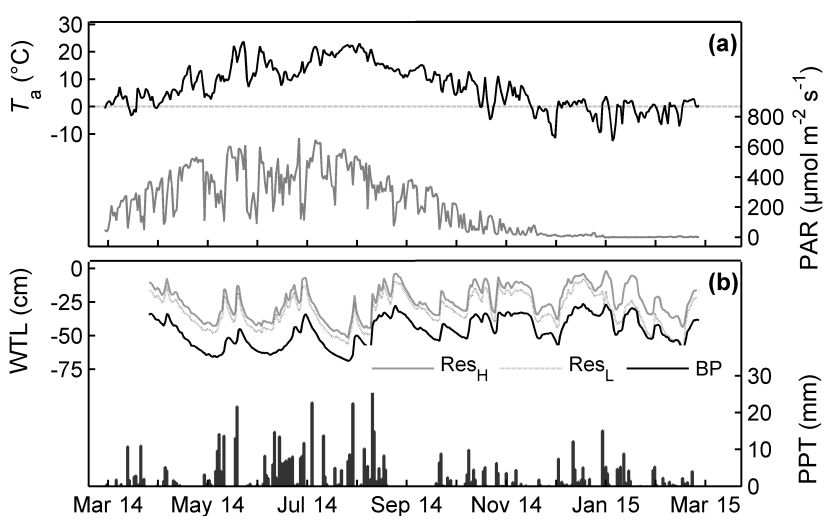

Figure 1. (a) Daily means of air temperature $\left(T_{\mathrm{a}}\right)$ and photosynthetically active radiation (PAR) and (b) daily sums of precipitation (PPT) and daily means of water table level (WTL) in restoration treatments with high $\left(\operatorname{Res}_{\mathrm{H}}\right)$ and low $\left(\operatorname{Res}_{\mathrm{L}}\right) \mathrm{WTL}$, and bare peat (BP) from March 2014 to February 2015; $T_{\mathrm{a}}$, PAR and PPT data are taken from the Viljandi and Tartu meteorological stations (until 17 June) and measured at the study site (from 18 June onward).

\subsection{Statistical analysis}

Collar flux data were averaged for each plot before conducting further statistical analysis to avoid pseudoreplication. The non-parametric Friedman one-way analysis of variance (ANOVA) by ranks test for dependent samples was used to account for repeated measurements in time when testing for treatment effects (i.e., $\operatorname{Res}_{\mathrm{H}}, \operatorname{Res}_{\mathrm{L}}$ and $\mathrm{BP}$ ) on the growing season or annual means of the various component fluxes. This analysis was followed by a Bonferroni post hoc comparison to determine significant differences among treatment means. The Mann-Whitney $U$ test was used when comparing only the restoration treatments for significant effects (i.e., on GPP, NPP and $R_{\mathrm{a}}$ fluxes). Pearson's correlations were used to investigate the effects of vegetation cover on mean growing season fluxes. The significance level was $P<0.05$ unless stated otherwise. All calculations and statistics were computed using the Matlab software (Matlab Student version, 2013a, Mathworks, USA).

\section{Results}

\subsection{Environmental conditions}

The annual mean $T_{\mathrm{a}}$ and total PPT from March 2014 to February 2015 were $7.2^{\circ} \mathrm{C}$ and $784 \mathrm{~mm}$, respectively, which suggests warmer conditions with normal wetness when compared to the long-term climate normal $\left(5.8^{\circ} \mathrm{C}\right.$ and $\left.764 \mathrm{~mm}\right)$. PAR peaked in the first week of July while the seasonal $T_{\mathrm{a}}$ curve peaked at around $23{ }^{\circ} \mathrm{C}$ in late July (Fig. 1a). A prolonged warm and dry period occurred from early to late July with a mean $T_{\mathrm{a}}$ of $20.0^{\circ} \mathrm{C}$ and total rainfall of $43.3 \mathrm{~mm}$.
Table 3. Vegetation cover (\%) inside the collars for greenhouse gas flux measurements in restoration treatments with high $\left(\operatorname{Res}_{\mathrm{H}}\right)$ and low $\left(\operatorname{Res}_{\mathrm{L}}\right)$ water table level. Total surface cover represents the area of bare peat surface re-colonized by vegetation; numbers in parenthesis indicate the range among individual collars.

\begin{tabular}{lll}
\hline Species & $\operatorname{Res}_{\mathrm{H}}$ & $\operatorname{Res}_{\mathrm{L}}$ \\
\hline Bryophytes & $62(32$ to 93$)$ & $44(15$ to 74$)$ \\
Sphagnum mosses & $61(31$ to 91$)$ & $43(12$ to 70$)$ \\
Vascular plants & $4(2$ to 9$)$ & $14(5$ to 22$)$ \\
Shrubs and tree seedlings & $2(0$ to 7$)$ & $13(5$ to 22$)$ \\
Sedges & $<1$ & $<1$ \\
\hline Total surface cover & $63(35$ to 95$)$ & $52(20$ to 85$)$ \\
\hline
\end{tabular}

The WTL ranged from -2 to -52 and from -8 to $-59 \mathrm{~cm}$ in the restored $\operatorname{Res}_{\mathrm{H}}$ and $\operatorname{Res}_{\mathrm{L}}$ treatments, respectively, while remaining between -26 and $-69 \mathrm{~cm}$ in the unrestored BP site (Fig. 1b). The mean WTLs in $\operatorname{Res}_{\mathrm{H}}$ and $\operatorname{Res}_{\mathrm{L}}$ were -24 and $-31 \mathrm{~cm}$, respectively, resulting in a mean annual difference of $7 \mathrm{~cm}$ between the restored treatments. Throughout the year, the WTL in $\operatorname{Res}_{H}$ was always higher than in $\operatorname{Res}_{\mathrm{L}}$ with the difference varying between 3 and $10 \mathrm{~cm}$. The mean WTL in BP was $-46 \mathrm{~cm}$ resulting in mean differences of -22 and $-15 \mathrm{~cm}$ compared to $\operatorname{Res}_{\mathrm{H}}$ and $\operatorname{Res}_{\mathrm{L}}$, respectively.

\subsection{Vegetation cover and composition}

The total surface cover, i.e., the fraction of re-colonized surface area, inside the flux measurement collars was higher in the wetter $\operatorname{Res}_{\mathrm{H}}(63 \%)$ than in the drier $\operatorname{Res}_{\mathrm{L}}(52 \%)$ treatment. Bryophytes were more abundant in $\operatorname{Res}_{\mathrm{H}}(62 \%)$ than in $\operatorname{Res}_{\mathrm{L}}(44 \%)$ (Table 3). The bryophyte cover consisted primarily of Sphagnum species which contributed 98 and $96 \%$ in $\operatorname{Res}_{\mathrm{H}}$ and $\operatorname{Res}_{\mathrm{L}}$, respectively. Vascular plants occurred more frequently in the drier $\operatorname{Res}_{\mathrm{L}}(14 \%)$ than in the wetter $\operatorname{Res}_{\mathrm{H}}(4 \%)$ treatment and were dominated by woody plants (i.e., shrubs and tree seedlings) (Table 3 ). The cover of sedges was $<1 \%$ in both restored treatments.

\subsection{Carbon dioxide fluxes}

Daytime NEE was positive indicating $\mathrm{CO}_{2}$ emissions during the non-growing-season months (November to April) in all three treatments (Fig. 2a). During the early (i.e., June) and late (i.e., mid-August to September) summer, net $\mathrm{CO}_{2}$ uptake occurred in both $\operatorname{Res}_{\mathrm{H}}$ and $\operatorname{Res}_{\mathrm{L}}$ with maximum rates of -42 and $-41 \mathrm{mg} \mathrm{C} \mathrm{m}^{-2} \mathrm{~h}^{-1}$, respectively. However, during the warm and dry mid-summer period, $\mathrm{CO}_{2}$ emissions of up to 36 and $27 \mathrm{mg} \mathrm{Cm}^{-2} \mathrm{~h}^{-1}$ were observed in $\operatorname{Res}_{\mathrm{H}}$ and $\mathrm{Res}_{\mathrm{L}}$, respectively. In contrast, NEE remained positive in BP throughout the growing season and followed the seasonal pattern of $T_{\mathrm{a}}$ with maximum emission rates of $104 \mathrm{mg} \mathrm{C} \mathrm{m}^{-2} \mathrm{~h}^{-1}$ occurring in early August. The annual mean midday NEEs in $\operatorname{Res}_{H}$ and $\operatorname{Res}_{\mathrm{L}}$ were significantly 
lower than in BP but not significantly different between the two restored treatments (Table 4).

Midday $R_{\mathrm{e}}$ was similar for all treatments during the nongrowing-season months (Fig. 2b). During the growing season, however, midday $R_{\mathrm{e}}$ differed among treatments with lowest and highest $R_{\mathrm{e}}$ observed in $\mathrm{Res}_{\mathrm{H}}$ and $\mathrm{BP}$, respectively. $R_{\mathrm{e}}$ in $\operatorname{Res}_{\mathrm{H}}$ and $\operatorname{Res}_{\mathrm{L}}$ reached maximum values of 74 and $96 \mathrm{mg} \mathrm{C} \mathrm{m}^{-2} \mathrm{~h}^{-1}$ during early July, respectively, whereas $R_{\mathrm{e}}$ peaked at $104 \mathrm{mg} \mathrm{C} \mathrm{m}^{-2} \mathrm{~h}^{-1}$ in early August in BP. The annual mean midday $R_{\mathrm{e}}$ was significantly lower in $\operatorname{Res}_{\mathrm{H}}$ and Res $_{\mathrm{L}}$ than in BP (Table 4).

From early June to late August, both the daytime GPP and NPP were more negative (i.e., representing greater production) in the drier $\operatorname{Res}_{\mathrm{L}}$ than in the wetter $\operatorname{Res}_{\mathrm{H}}$ treatment (Fig. 2c, d). Greatest GPP occurred in late June and midAugust reaching -90 and $-98 \mathrm{mg} \mathrm{C} \mathrm{m}^{-2} \mathrm{~h}^{-1}$ in $\mathrm{Res}_{\mathrm{H}}$ and $\operatorname{Res}_{\mathrm{L}}$, respectively. GPP temporarily decreased (i.e., resulting in less negative values) to -14 and $-41 \mathrm{mg} \mathrm{C} \mathrm{m}^{-2} \mathrm{~h}^{-1}$ during the warm and dry mid-summer period in both $\mathrm{Res}_{\mathrm{H}}$ and $\operatorname{Res}_{\mathrm{L}}$. The seasonal patterns of NPP followed closely those of GPP, reaching -65 and $-68 \mathrm{mg} \mathrm{Cm}^{-2} \mathrm{~h}^{-1}$ in Res $\mathrm{H}_{\mathrm{H}}$ and $\operatorname{Res}_{L}$, respectively. The growing season mean GPP in $\operatorname{Res}_{H}$ $\left(-49.3 \mathrm{mg} \mathrm{C} \mathrm{m}^{-2} \mathrm{~h}^{-1}\right)$ was significantly higher than that in $\operatorname{Res}_{\mathrm{L}}\left(-65.5 \mathrm{mg} \mathrm{C} \mathrm{m}^{-2} \mathrm{~h}^{-1}\right.$ ) (Table 4). The difference in the growing season means of NPP in $\operatorname{Res}_{\mathrm{H}}$ and $\mathrm{Res}_{\mathrm{L}}$ was not statistically significant.

Midday $R_{\mathrm{a}}$ was more than 2 times greater in the drier $\operatorname{Res}_{\mathrm{L}}$ than in the wetter $\operatorname{Res}_{\mathrm{H}}$ treatment for most of the growing season sampling dates (Fig. 2e). The seasonal pattern of $R_{\mathrm{a}}$ coincided with that of GPP in both restored treatments with greatest $R_{\mathrm{a}}$ occurring in late June and mid-August, reaching maximum values of up to 27 and $36 \mathrm{mg} \mathrm{C} \mathrm{m}^{-2} \mathrm{~h}^{-1}$ in $\operatorname{Res}_{\mathrm{H}}$ and $\operatorname{Res}_{\mathrm{L}}$, respectively. The growing season mean $R_{\mathrm{a}}$ was significantly higher (by about 2 times) in $\operatorname{Res}_{\mathrm{L}}$ than in $\operatorname{Res}_{\mathrm{H}}$ (Table 4). The ratio of $R_{\mathrm{a}}$ to $R_{\mathrm{h}}$ was on average 0.21 and 0.42 in $\operatorname{Res}_{\mathrm{H}}$ and $\operatorname{Res}_{\mathrm{L}}$, respectively.

Midday $R_{\mathrm{h}}$ was consistently lower in $\operatorname{Res}_{\mathrm{H}}$ and $\mathrm{Res}_{\mathrm{L}}$ than in BP throughout the growing season (Fig. 2f). Maximum $R_{\mathrm{h}}$ of up to 61,73 and $104 \mathrm{mg} \mathrm{C} \mathrm{m}^{-2} \mathrm{~h}^{-1}$ in $\operatorname{Res}_{\mathrm{H}}, \operatorname{Res}_{\mathrm{L}}$ and BP, respectively, were observed in early July (restored treatments) and early August (unrestored BP). The growing season mean $R_{\mathrm{h}}$ was significantly lower (by about $50 \%$ ) in Res $_{H}$ and $\operatorname{Res}_{\mathrm{L}}$ than in BP (Table 4).

\subsection{Methane fluxes}

Throughout most of the year, $\mathrm{CH}_{4}$ fluxes were observed in the range of -13 to $60 \mu \mathrm{g} \mathrm{m}^{-2} \mathrm{~h}^{-1}$ in all three treatments (Fig. 3a). However, occasional peak $\mathrm{CH}_{4}$ emission of up to 170 and $92 \mu \mathrm{g} \mathrm{Cm}^{-2} \mathrm{~h}^{-1}$ occurred in $\operatorname{Res}_{\mathrm{H}}$ and $\mathrm{Res}_{\mathrm{L}}$, respectively. During the non-growing-season months, $\mathrm{CH}_{4}$ exchange was variable, showing both small uptake as well as large emission ( -6 to $138 \mu \mathrm{g} \mathrm{C} \mathrm{m}^{-2} \mathrm{~h}^{-1}$ ). The mean annual $\mathrm{CH}_{4}$ exchange was about 2 times greater in the wetter $\mathrm{Res}_{\mathrm{H}}$ than in the drier $\operatorname{Res}_{\mathrm{L}}$ treatment although the differences

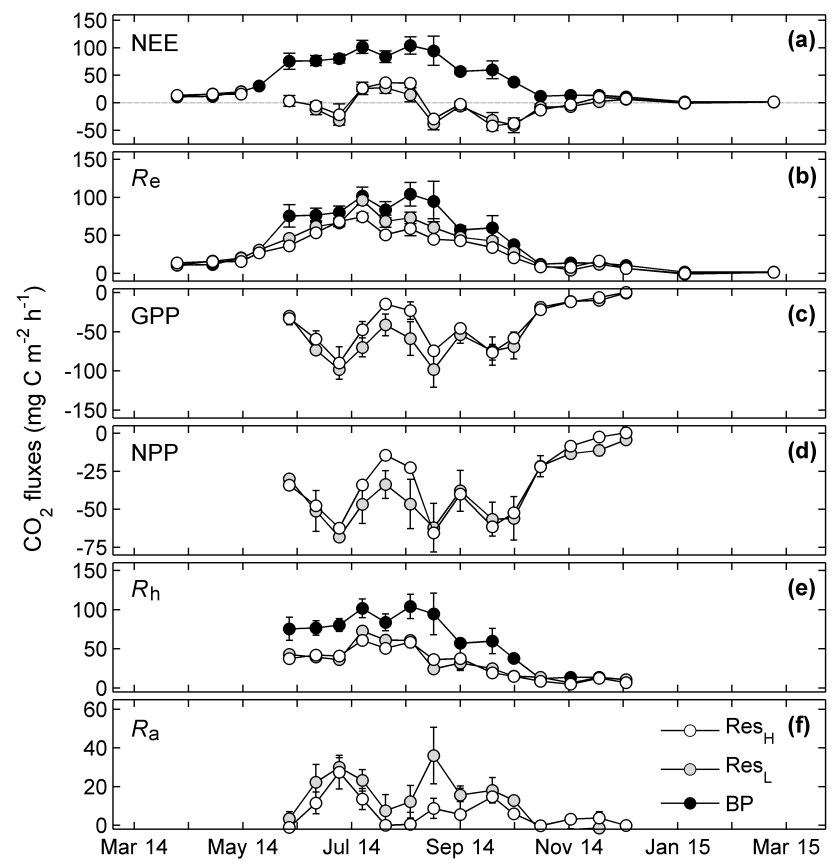

Figure 2. (a) Net ecosystem $\mathrm{CO}_{2}$ exchange (NEE), (b) ecosystem respiration $\left(R_{\mathrm{e}}\right)$, (c) gross primary production (GPP), (d) net primary production (NPP), (e) autotrophic respiration $\left(R_{\mathrm{a}}\right)$ and (f) heterotrophic respiration $\left(R_{\mathrm{h}}\right)$ in restoration treatments with high $\left(\operatorname{Res}_{\mathrm{H}}\right)$ and low $\left(\operatorname{Res}_{\mathrm{L}}\right)$ water table level and bare peat (BP); error bars indicate standard error; the horizontal dotted line in (a) visualizes the zero line above and below which $\mathrm{CO}_{2}$ emission and uptake occur, respectively.

Table 4. Means of measured $\mathrm{CO}_{2}$ fluxes $\left(\mathrm{mg} \mathrm{C} \mathrm{m}^{-2} \mathrm{~h}^{-1}\right)$ including net ecosystem exchange (NEE), ecosystem respiration $\left(R_{\mathrm{e}}\right)$, gross primary production (GPP), net primary production (NPP), autotrophic respiration $\left(R_{\mathrm{a}}\right)$ and heterotrophic respiration $\left(R_{\mathrm{h}}\right)$, as well as means of measured methane $\left(\mathrm{CH}_{4} ; \mu \mathrm{g} \mathrm{C} \mathrm{m}^{-2} \mathrm{~h}^{-1}\right)$ and nitrous oxide $\left(\mathrm{N}_{2} \mathrm{O} ; \mu \mathrm{g} \mathrm{N} \mathrm{m}{ }^{-2} \mathrm{~h}^{-1}\right)$ fluxes in restoration treatments with high $\left(\operatorname{Res}_{H}\right)$ and low $\left(\operatorname{Res}_{\mathrm{L}}\right)$ water table level and bare peat (BP); negative and positive fluxes represent uptake and emission, respectively; numbers in parenthesis indicate standard error; different letters indicate significant $(P<0.05)$ differences among treatments.

\begin{tabular}{llll}
\hline Component flux & $\operatorname{Res}_{\mathrm{H}}$ & $\operatorname{Res}_{\mathrm{L}}$ & $\mathrm{BP}$ \\
\hline $\mathrm{NEE}$ & $0.57(4.9)^{\mathrm{c}}$ & $-2.82(4.9)^{\mathrm{c}}$ & $44.9(8.2)^{\mathrm{ab}}$ \\
$R_{\mathrm{e}}$ & $29.9(5.1)^{\mathrm{c}}$ & $35.1(6.4)^{\mathrm{c}}$ & $44.9(8.2)^{\mathrm{ab}}$ \\
$\mathrm{GPP}^{*}$ & $-49.3(7.4)^{\mathrm{a}}$ & $-65.5(7.3)^{\mathrm{b}}$ & $\mathrm{n} / \mathrm{a}$ \\
$\mathrm{NPP}^{*}$ & $-41.5(5.3)$ & $-48.1(4.2)$ & $\mathrm{n} / \mathrm{a}$ \\
$R_{\mathrm{a}}^{*}$ & $7.9(2.6)^{\mathrm{a}}$ & $16.2(3.4)^{\mathrm{b}}$ & $\mathrm{n} / \mathrm{a}$ \\
$R_{\mathrm{h}}^{*}$ & $37.0(5.1)^{\mathrm{c}}$ & $38.5(5.9)^{\mathrm{c}}$ & $71.2(8.4)^{\mathrm{ab}}$ \\
$\mathrm{CH}_{4}$ & $23.0(10.7)$ & $10.9(6.1)$ & $14.7(3.7)$ \\
$\mathrm{N}_{2} \mathrm{O}$ & $-0.12(0.25)^{\mathrm{c}}$ & $2.13(1.29)^{\mathrm{c}}$ & $27.1(9.1)^{\mathrm{ab}}$ \\
\hline
\end{tabular}

* Growing season mean (1 May to October 31); n/a is not applicable. 


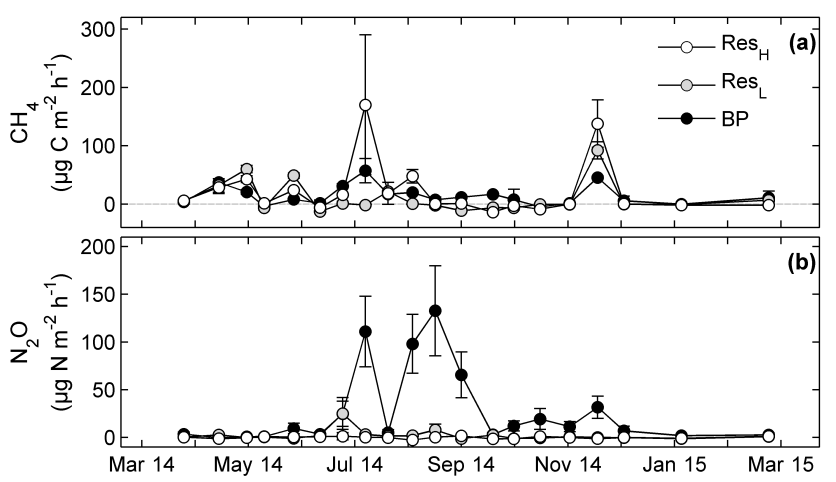

Figure 3. Measured fluxes of (a) methane $\left(\mathrm{CH}_{4} ; \mu \mathrm{g} \mathrm{C} \mathrm{m}^{-2} \mathrm{~h}^{-1}\right)$ and (b) nitrous oxide $\left(\mathrm{N}_{2} \mathrm{O} ; \mu \mathrm{g} \mathrm{N} \mathrm{m} \mathrm{N}^{-2} \mathrm{~h}^{-1}\right)$ in restoration treatments with high $\left(\operatorname{Res}_{H}\right)$ and low $\left(\operatorname{Res}_{\mathrm{L}}\right)$ water table level and bare peat (BP); error bars indicate standard error; the horizontal dotted line in (a) visualizes the zero line above and below which $\mathrm{CH}_{4}$ emission and uptake occur, respectively.

among the three treatments were not statistically significant (Table 4).

\subsection{Nitrous oxide fluxes}

$\mathrm{N}_{2} \mathrm{O}$ fluxes in $\mathrm{Res}_{\mathrm{H}}$ and $\mathrm{Res}_{\mathrm{L}}$ remained within the range of -2.8 to $25 \mu \mathrm{g} \mathrm{N} \mathrm{m}^{-2} \mathrm{~h}^{-1}$ for most of the year (Fig. 3b). In contrast, high $\mathrm{N}_{2} \mathrm{O}$ emissions of 66 to $133 \mu \mathrm{g} \mathrm{N} \mathrm{m}{ }^{-2} \mathrm{~h}^{-1}$ occurred during July and August in BP. The annual mean $\mathrm{N}_{2} \mathrm{O}$ exchanges of $-0.12 \mu \mathrm{g} \mathrm{N} \mathrm{m}^{-2} \mathrm{~h}^{-1}$ in $\operatorname{Res}_{\mathrm{H}}$ and $2.13 \mu \mathrm{g} \mathrm{N} \mathrm{m}^{-2} \mathrm{~h}^{-1}$ in $\operatorname{Res}_{\mathrm{L}}$ were not significantly different (Table 4). Meanwhile, the mean $\mathrm{N}_{2} \mathrm{O}$ exchanges in the two restored treatments were significantly lower (by 1-2 magnitudes) compared to the $27.1 \mu \mathrm{g} \mathrm{N} \mathrm{m}^{-2} \mathrm{~h}^{-1}$ in BP (Table 4).

\subsection{Biotic and abiotic controls of GHG fluxes}

The differences in mean growing season NEE, GPP, NPP and $R_{\mathrm{a}}$ among individual collars (i.e., the spatial variability) were significantly correlated to bryophyte but not to vascular plant cover in $\mathrm{Res}_{\mathrm{H}}$ (Table 5). In contrast, spatial variations in NEE, GPP, NPP and $R_{\mathrm{a}}$ were significantly correlated to vascular plant but not to bryophyte cover in $\mathrm{Res}_{\mathrm{L}}$. In addition, $R_{\mathrm{e}}$ was significantly correlated to vascular plant cover in $\mathrm{Res}_{\mathrm{L}}$. Meanwhile, the $\mathrm{CH}_{4}$ and $\mathrm{N}_{2} \mathrm{O}$ exchanges were not significantly correlated to vegetation cover in either $\operatorname{Res}_{\mathrm{H}}$ or $\operatorname{Res}_{\mathrm{L}}$.

$T_{\mathrm{S}}$ measured at $10 \mathrm{~cm}$ depth was the abiotic variable that best explained variations in $R_{\mathrm{e}}\left(R^{2}=0.79,0.84\right.$ and 0.81 in $\operatorname{Res}_{\mathrm{H}}, \operatorname{Res}_{\mathrm{L}}$ and BP, respectively) in the form of an exponential relationship (Fig. 4) with higher temperatures resulting in higher respiration rates. The basal respiration and temperature sensitivity parameters were lowest in the wetter $\operatorname{Res}_{\mathrm{H}}$ treatment and highest in $\mathrm{BP}$.

$\mathrm{N}_{2} \mathrm{O}$ fluxes correlated best with VWC measured at 0 $5 \mathrm{~cm}$ soil depth in $\operatorname{Res}_{\mathrm{L}}\left(R^{2}=0.60\right)$ and in $\mathrm{BP}\left(R^{2}=0.39\right)$

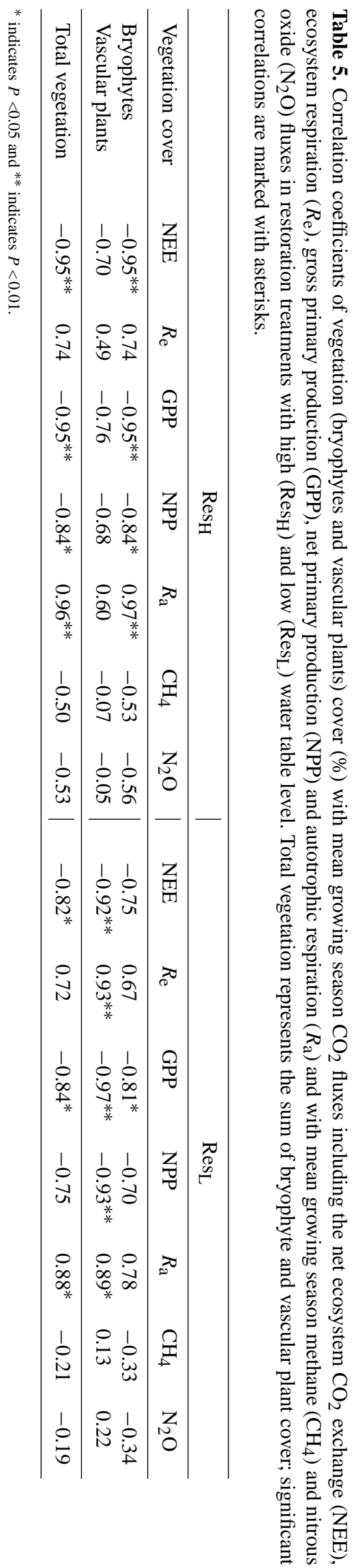

www.biogeosciences.net/13/2637/2016/ 
Table 6. Growing season (GS; 1 May to 31 October) and annual $(A)$ sums of the carbon balance components $\left(\mathrm{g} \mathrm{C}^{-2}\right)$ including gross primary production $(\mathrm{GPP})$, ecosystem respiration $\left(R_{\mathrm{e}}\right)$, net ecosystem exchange $(\mathrm{NEE})$ of $\mathrm{CO}_{2}$ and methane $\left(\mathrm{CH}_{4}\right)$ fluxes, as well as the greenhouse gas $(\mathrm{GHG})$ balance components $\left(\mathrm{tCO}_{2} \mathrm{eq} \mathrm{ha}^{-1}\right)$ including $\mathrm{NEE}, \mathrm{CH}_{4}$ and nitrous oxide $\left(\mathrm{N}_{2} \mathrm{O}\right)$ exchanges (using global warming potentials of 34 and 298 for $\mathrm{CH}_{4}$ and $\mathrm{N}_{2} \mathrm{O}$, respectively) in restoration treatments with high $\left(\mathrm{Res}_{\mathrm{H}}\right)$ and low (Res $\left.\mathrm{L}_{\mathrm{L}}\right)$ water table level and bare peat (BP); negative and positive fluxes represent uptake and emission, respectively.

\begin{tabular}{|c|c|c|c|c|c|c|}
\hline \multirow[b]{2}{*}{ Component flux } & \multicolumn{2}{|c|}{$\operatorname{Res}_{H}$} & \multicolumn{2}{|c|}{$\operatorname{Res}_{L}$} & \multicolumn{2}{|c|}{$\mathrm{BP}$} \\
\hline & GS & $A$ & GS & $A$ & GS & $A$ \\
\hline \multicolumn{7}{|l|}{$\mathrm{C}$ balance components } \\
\hline GPP & -78.0 & -78.0 & -110.5 & -110.5 & $\mathrm{n} / \mathrm{a}$ & $\mathrm{n} / \mathrm{a}$ \\
\hline$R_{\mathrm{e}}$ & 127.5 & 188.6 & 148.8 & 213.2 & 180.5 & 267.8 \\
\hline NEE & 49.5 & 110.6 & 38.3 & 102.7 & $180.5^{\mathrm{a}}$ & $267.8^{\mathrm{a}}$ \\
\hline $\mathrm{CH}_{4}$ & 0.130 & 0.190 & 0.036 & 0.117 & 0.076 & 0.137 \\
\hline Total C balance ${ }^{\mathrm{b}}$ & & 110.8 & & 102.8 & & 268.0 \\
\hline \multicolumn{7}{|c|}{ GHG balance components } \\
\hline NEE & 1.81 & 4.05 & 1.40 & 3.76 & 6.62 & 9.82 \\
\hline $\mathrm{CH}_{4}$ & 0.059 & 0.086 & 0.016 & 0.053 & 0.035 & 0.062 \\
\hline $\mathrm{N}_{2} \mathrm{O}$ & 0.002 & 0.004 & 0.010 & 0.020 & 0.167 & 0.332 \\
\hline Total GHG balance ${ }^{\mathrm{c}}$ & & 4.14 & & 3.83 & & 10.21 \\
\hline
\end{tabular}

${ }^{\mathrm{a}}$ GPP for BP was assumed to be 0 and NEE therefore equal to $R_{\mathrm{e}}{ }^{\mathrm{b}}$ The total $\mathrm{C}$ balance $\left(\mathrm{g} \mathrm{C} \mathrm{m}^{-2} \mathrm{yr}^{-1}\right)$ is the sum of NEE and $\mathrm{CH}_{4}$ fluxes. ${ }^{\mathrm{c}}$ The total GHG balance $\left(\mathrm{tCO}_{2} \mathrm{eq} \mathrm{ha}^{-1} \mathrm{yr}^{-1}\right)$ is the sum of $\mathrm{NEE}, \mathrm{CH}_{4}$ and $\mathrm{N}_{2} \mathrm{O}$ fluxes. $\mathrm{n} / \mathrm{a}$ is not applicable.

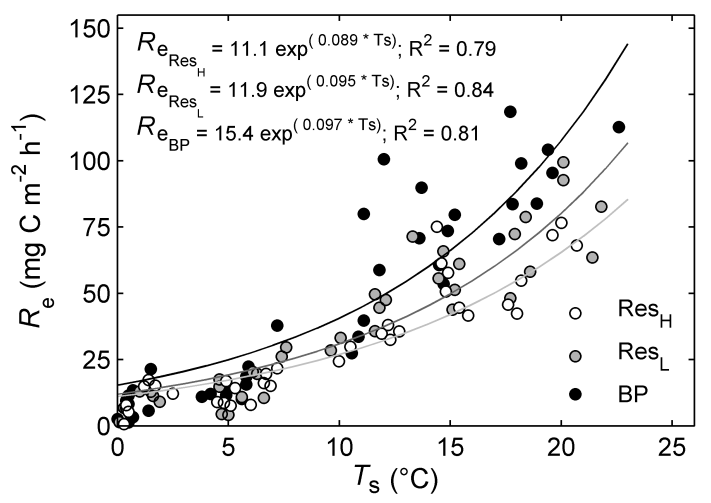

Figure 4. Response of ecosystem respiration $\left(R_{\mathrm{e}} ; \mathrm{mg} \mathrm{C} \mathrm{m}^{-2} \mathrm{~h}^{-1}\right)$ to changes in soil temperature $\left(T_{\mathrm{S}}\right)$ measured at $10 \mathrm{~cm}$ soil depth in restoration treatments with high $\left(\operatorname{Res}_{\mathrm{H}}\right)$ and low $\left(\operatorname{Res}_{\mathrm{L}}\right)$ water table level and bare peat (BP).

(Fig. 5). In contrast, $\mathrm{N}_{2} \mathrm{O}$ fluxes were not correlated to soil VWC or any other abiotic variable in $\mathrm{Res}_{\mathrm{H}}$. Similarly, the $\mathrm{CH}_{4}$ exchange did not show any significant relationships with any abiotic variable for any of the three treatments.

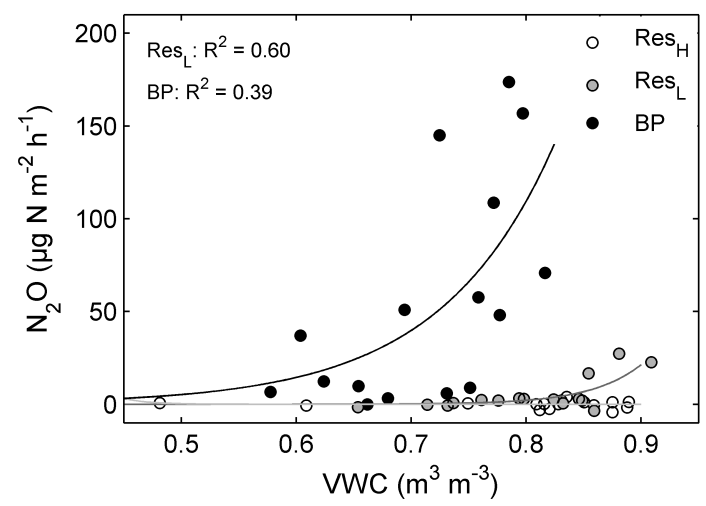

Figure 5. Response of nitrous oxide $\left(\mathrm{N}_{2} \mathrm{O}\right)$ fluxes $\left(\mu \mathrm{g} \mathrm{N} \mathrm{m}^{-2} \mathrm{~h}^{-1}\right)$ to changes in volumetric water content (VWC) measured at $0-5 \mathrm{~cm}$ soil depth during the growing season in restoration treatments with high $\left(\operatorname{Res}_{H}\right)$ and low $\left(\operatorname{Res}_{\mathrm{L}}\right)$ water table level and bare peat (BP).

\subsection{Annual carbon and GHG balances}

In the restored $\operatorname{Res}_{\mathrm{H}}$ and $\mathrm{Res}_{\mathrm{L}}$ treatments, the modeled annual $R_{\mathrm{e}}$ estimates were 188.6 and $213.2 \mathrm{~g} \mathrm{C} \mathrm{m}^{-2} \mathrm{yr}^{-1}$, respectively, whereas in the unrestored BP treatment annual $R_{\mathrm{e}}$ was $267.8 \mathrm{~g} \mathrm{C} \mathrm{m}^{-2} \mathrm{yr}^{-1}$ (Table 6). The annual GPP was estimated at -78.0 and $-110.5 \mathrm{~g} \mathrm{C} \mathrm{m}^{-2} \mathrm{yr}^{-1}$ in $\operatorname{Res}_{\mathrm{H}}$ and $\operatorname{Res}_{\mathrm{L}}$, respectively. This resulted in annual NEEs of 110.6, 102.7 and $267.8 \mathrm{~g} \mathrm{C} \mathrm{m}^{-2} \mathrm{yr}^{-1}$ in the wetter $\operatorname{Res}_{\mathrm{H}}$, drier $\operatorname{Res}_{\mathrm{L}}$ and $\mathrm{BP}$ treatments, respectively. The growing season net 
$\mathrm{CO}_{2}$ loss represented 45 and $37 \%$ of the annual NEE in Res $_{H}$ and Res $s_{L}$, respectively, while it accounted for $67 \%$ in BP. The additional $\mathrm{C}$ losses via $\mathrm{CH}_{4}$ emission were 0.190 , 0.117 and $0.137 \mathrm{~g} \mathrm{C} \mathrm{m}^{-2} \mathrm{yr}^{-1}$ in $\operatorname{Res}_{\mathrm{H}}$, $\operatorname{Res}_{\mathrm{L}}$ and $\mathrm{BP}$, respectively. In total, all treatments acted as $\mathrm{C}$ sources; however, the annual $\mathrm{C}$ balance was lower in the restored $\mathrm{Res}_{\mathrm{H}}$ $\left(110.8 \mathrm{~g} \mathrm{C} \mathrm{m}^{-2} \mathrm{yr}^{-1}\right)$ and $\operatorname{Res}_{\mathrm{L}}\left(102.8 \mathrm{~g} \mathrm{C} \mathrm{m}^{-2} \mathrm{yr}^{-1}\right)$ treatments than in the unrestored BP $\left(268.0 \mathrm{~g} \mathrm{C} \mathrm{m}^{-2} \mathrm{yr}^{-1}\right)$ treatment. The total GHG balance, including NEE as well as $\mathrm{CH}_{4}$ and $\mathrm{N}_{2} \mathrm{O}$ emissions expressed as $\mathrm{CO}_{2}$ eq, was 4.14, 3.83 and $10.21 \mathrm{tCO}_{2} \mathrm{eq} \mathrm{ha}^{-1} \mathrm{yr}^{-1}$ in $\operatorname{Res}_{\mathrm{H}}, \mathrm{Res}_{\mathrm{L}}$ and BP, respectively (Table 6). The GHG balance was driven by NEE (96 to 98\%) in all three treatments. The contribution of $\mathrm{CH}_{4}$ emission was highest $(2.1 \%)$ in the wetter $\operatorname{Res}_{\mathrm{H}}$ treatment, while the contribution of $\mathrm{N}_{2} \mathrm{O}$ emission was highest $(3.9 \%)$ in the unrestored BP treatment.

\section{Discussion}

\subsection{GHG fluxes and their controls in restored and abandoned peat extraction areas}

\subsubsection{Coupling of water table level and vegetation dynamics}

Three years following restoration, contrasting vegetation communities in $\operatorname{Res}_{\mathrm{H}}$ and $\operatorname{Res}_{\mathrm{L}}$ had developed as a result of a mean annual WTL difference of $7 \mathrm{~cm}$. Specifically, a greater cover of bryophytes (63\%) (primarily Sphagnum spp.), which rely on capillary forces for acquiring water and thus require moist conditions (Rydin, 1985), was present in the wetter $\operatorname{Res}_{\mathrm{H}}$ treatment. In contrast, the lower WTL in $\operatorname{Res}_{L}$ resulted in a lower bryophyte cover (44\%) but greater abundance of vascular plants, likely due to the extended zone of aeration for plant roots. Apart from having roots to absorb water and nutrients from the soil, vascular plants also differ from bryophytes by having leaf stomata to regulate water transport and $\mathrm{CO}_{2}$ exchange (Turner et al., 1985; Schulze et al., 1994). Thus, the establishment of contrasting vegetation communities as a result of different WTL baselines has potential implications for the biogeochemical cycles and GHG fluxes following peatland restoration (Weltzin et al., 2000).

\subsubsection{Carbon dioxide fluxes}

In this study, the significantly higher GPP in $\operatorname{Res}_{\mathrm{L}}$ was likely due to the greater vascular plant cover compared to $\operatorname{Res}_{\mathrm{H}}$, since vascular plants reach higher photosynthesis rates at higher light levels compared to mosses (Bubier et al., 2003; Riutta et al., 2007a). Similarly, Strack and Zuback (2013) reported a strong correlation between vascular plant cover and GPP in a restored peatland in Canada. In return, the greater GPP also explains the higher $R_{\mathrm{a}}$ observed in $\operatorname{Res}_{\mathrm{L}}$ compared to $\operatorname{Res}_{\mathrm{H}}$. This highlights the implications of hydrological differences and the associated vegetation development on plant-related $\mathrm{CO}_{2}$ fluxes. Furthermore, it has been suggested that the presence of vascular plants can facilitate greater survival and better growth of the re-introduced mosses as they can provide shelter from the intense solar radiation and wind and thus create a more favorable micro-climate (Ferland and Rochefort, 1997; Tuittila et al., 2000b; McNeil and Waddington, 2003; Pouliot et al., 2012). Since Sphagnum mosses are generally more sensitive to drought compared to vascular plants, restoration strategies allowing the development of a diverse vegetation cover (i.e., bryophytes accompanied by vascular plants) could therefore be considered to have greater potential for limiting the $\mathrm{CO}_{2}$ loss and regaining the C sink function (Tuittila et al., 1999). Nevertheless, despite the significant effects of the re-established WTL baseline on vegetation development and the associated $\mathrm{CO}_{2}$ component fluxes (i.e., $R_{\mathrm{e}}$ and GPP), the NEE of the two restored treatments was similar. Our study therefore suggests that the greater GPP was partly counterbalanced by greater $R_{\mathrm{a}}$ in $\operatorname{Res}_{\mathrm{L}}$ compared to Res $\mathrm{H}_{\mathrm{H}}$. However, while differences in the re-established WTL baseline had no significant effect on the $\mathrm{CO}_{2}$ sink-source strength 3 years after restoration of the abandoned peat extraction area, vegetation characteristics are likely to further diverge in the future which might essentially result in contrasting net $\mathrm{CO}_{2}$ balances over longer time spans (Weltzin et al., 2000; Yli-Petäys et al., 2007; Samaritani et al., 2011; Vanselow-Algan et al., 2015).

Compared to the unrestored BP treatment, growing season $R_{\mathrm{h}}$ was considerably reduced in the restored treatments which suggests that raising the WTL effectively mitigated C losses from the ecosystem by reducing the potential for aerobic peat decomposition (Silvola et al., 1996; Frolking et al., 2001; Whiting and Chanton, 2001). Furthermore, the significantly lower $R_{\mathrm{e}}$ in $\operatorname{Res}_{\mathrm{H}}$ and $\operatorname{Res}_{\mathrm{L}}$ compared to BP demonstrates that the additional $R_{\mathrm{a}}$ from the vegetation was negligible compared to the large reduction in $R_{\mathrm{h}}$. Likewise, Strack and Zuback (2013) found a significantly lower $R_{\mathrm{h}}$ and $R_{\mathrm{e}}$ in a restored compared to an unrestored site in Canada 10 years following peatland restoration. Furthermore, the lower $R_{\mathrm{e}}$ in the restored treatments relative to BP might also result from the lower temperature sensitivity of $R_{\mathrm{h}}$ observed in this study which is likely due to greater oxygen limitation in the restored treatments following the raising of the WTL. Thus, our findings highlight the effectiveness of raising the WTL in reducing peat decomposition and associated $\mathrm{CO}_{2}$ emissions from drained organic soils.

\subsubsection{Methane fluxes}

Both WTL and vegetation dynamics have been previously highlighted as major controls of the $\mathrm{CH}_{4}$ exchange in natural, restored and drained peatlands (Bubier, 1995; Frenzel and Karofeld, 2000; Tuittila et al., 2000a; Riutta et al., 2007b; Waddington and Day, 2007; Lai, 2009; Strack et al., 2014). Specifically, the WTL determines the depth of the lower anaerobic and the upper aerobic peat layers and thus the 
potential for $\mathrm{CH}_{4}$ production and consumption occurring in these respective layers (Bubier, 1995; Tuittila et al., 2000a). The relatively low mean annual WTLs (i.e., $-24,-31$ and $-46 \mathrm{~cm}$ in $\operatorname{Res}_{\mathrm{H}}, \operatorname{Res}_{\mathrm{L}}$ and $\mathrm{BP}$, respectively) might therefore explain the generally low $\mathrm{CH}_{4}$ emission rates observed in our study compared to those previously reported in similar ecosystems (Tuittila et al., 2000a; Basiliko et al., 2007; Waddington and Day, 2007; Lai, 2009; Vanselow-Algan et al., 2015). Nevertheless, high autumn peak emissions were observed in all treatments that might be caused by a rapid drop in the WTL during which $\mathrm{CH}_{4}$ may have been released from the pore water and emitted to the atmosphere as shown in previous studies (e.g., Windsor et al., 1992; Moore and Dalva, 1993). These episodic emission peaks indicate a potential for higher annual $\mathrm{CH}_{4}$ emissions following peatland restoration than those estimated in this study.

Vegetation composition affects the $\mathrm{CH}_{4}$ production through substrate supply (i.e., quality and quantity) (Saarnio et al., 2004; Ström et al., 2005) and by offering a direct emission pathway for $\mathrm{CH}_{4}$ from the deeper anaerobic layer to the atmosphere via the aerenchymatous cell tissue of deep rooting sedge species such as Eriophorum vaginatum (Thomas et al., 1996; Frenzel and Karofeld, 2000; Ström et al., 2005; Waddington and Day, 2007). Given the considerable differences in vegetation composition, the lack of significant effects on $\mathrm{CH}_{4}$ emissions among the restored and BP treatments in our study was surprising. Most likely, similar $\mathrm{CH}_{4}$ emissions in $\operatorname{Res}_{\mathrm{H}}$ and $\operatorname{Res}_{\mathrm{L}}$ were the result of opposing effects counterbalancing the production and consumption of $\mathrm{CH}_{4}$. For instance, enhanced anaerobic $\mathrm{CH}_{4}$ production due to the higher WTL in $\mathrm{Res}_{\mathrm{H}}$ could have been partly compensated by greater $\mathrm{CH}_{4}$ oxidation within or immediately below the more developed moss layer (Frenzel and Karofeld, 2000;

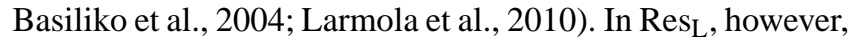
greater vascular plant substrate supply might have sustained substantial $\mathrm{CH}_{4}$ production despite a reduction of the anaerobic zone (Tuittila et al., 2000a; Weltzin et al., 2000). Also noteworthy is that, while very few aerenchymatous sedge species were established at the time of this study, a future increase in the sedge cover is likely to occur (Tuittila et al., 2000a; Weltzin et al., 2000; Vanselow-Algan et al., 2015) which could considerably increase the $\mathrm{CH}_{4}$ emission in the restored treatments over longer time spans. Overall, the potential effects from enhanced anaerobic conditions due to the raised WTL, $\mathrm{CH}_{4}$ oxidation in the moss layer or greater vascular plant substrate supply on the net $\mathrm{CH}_{4}$ fluxes were small, considering that $\mathrm{CH}_{4}$ emissions were not significantly different from those in BP which was characterized by a considerably lower WTL and absence of vegetation. Thus, our study suggests that in non-flooded conditions WTL changes following peatland restoration have a limited effect on the $\mathrm{CH}_{4}$ emissions during the initial few years.

\subsubsection{Nitrous oxide fluxes}

Soil moisture and WTL effects on the soil oxygen status have been previously identified as the main control of $\mathrm{N}_{2} \mathrm{O}$ emissions from pristine and drained peatlands (Firestone and Davidson, 1989; Martikainen et al., 1993; Klemedtsson et al., 2005). Highest $\mathrm{N}_{2} \mathrm{O}$ emissions commonly occur in mesic soils with intermediate WTLs, which allows both aerobic and anaerobic $\mathrm{N}_{2} \mathrm{O}$ production during nitrification and denitrification, respectively, while avoiding the anaerobic reduction of $\mathrm{N}_{2} \mathrm{O}$ to $\mathrm{N}_{2}$ (Firestone and Davidson, 1989; Martikainen et al., 1993). In addition, substrate supply (i.e., $\mathrm{C}$ and inorganic $\mathrm{N}$ ) is a key prerequisite for $\mathrm{N}_{2} \mathrm{O}$ production (Firestone and Davidson, 1989). In our study, similar $\mathrm{N}_{2} \mathrm{O}$ fluxes in the two restored treatments therefore suggest that the differences in WTL, soil moisture and substrate supply from mineralization of organic matter were too small to affect the magnitudes of $\mathrm{N}_{2} \mathrm{O}$ emission 3 years following restoration with different WTL baselines. In contrast, the enhanced anaerobic conditions due to a higher WTL as well as lower soil N concentrations due to reduced mineralization and enhanced plant $\mathrm{N}$ uptake might explain both the reduced $\mathrm{N}_{2} \mathrm{O}$ emissions and their lower sensitivity to soil moisture in the restored $\mathrm{Res}_{\mathrm{H}}$ and $\operatorname{Res}_{\mathrm{L}}$ treatments compared to BP. Thus, peatland restoration has the potential for reducing the $\mathrm{N}_{2} \mathrm{O}$ emissions commonly occurring in drained, abandoned peatlands by altering both soil hydrology and N substrate supply.

\subsection{The carbon and GHG balances of restored and abandoned peat extraction areas}

Both restored treatments were $\mathrm{C}$ sources during the growing season, which indicates that the $\mathrm{CO}_{2}$ uptake by the reestablished vegetation was not able to compensate for the $\mathrm{C}$ losses via respiration and $\mathrm{CH}_{4}$ emissions 3 years following restoration. Several studies have previously reported estimates for the growing season $\mathrm{C}$ sink-source strength of restored peatlands, with contrasting findings due to different restoration techniques, environmental conditions during the study year and time passed since the initiation of the restoration (Tuittila et al., 1999; Bortoluzzi et al., 2006; Yli-Petäys et al., 2007; Waddington et al., 2010; Samaritani et al., 2011; Strack et al., 2014). For instance, restored peatlands in Finland (Tuittila et al., 1999) and Canada (Waddington et al., 2010; Strack et al., 2014) were C sinks during the growing season 3 to 6 years after restoration. In contrast, other studies suggested that several decades may be required before restored peatlands resume their functioning as $\mathrm{C}$ sinks (YliPetäys et al., 2007; Samaritani et al., 2011). However, while growing season studies can provide important information on processes governing the fluxes, it is necessary to quantify and compare full annual budgets to better evaluate the climate benefits of peatland restoration relative to abandoned peatland areas (and other after-use options, e.g., afforestation or energy crop cultivation). 
In our study, the annual $\mathrm{C}$ source strength of the restored and BP treatments was about 1.5 to 2.5 times greater than on the growing season scale. This highlights the importance of accounting for the considerable non-growing-season emissions when evaluating the $\mathrm{C}$ sink potential of restored peatlands. In comparison, the annual $\mathrm{C}$ source strength of the two restored treatments (111 and $103 \mathrm{~g} \mathrm{C} \mathrm{m}^{-2} \mathrm{yr}^{-1}$ ) was lower than the annual emissions of $148 \mathrm{~g} \mathrm{C} \mathrm{m}^{-2} \mathrm{yr}^{-1}$ reported for a restored cutaway peatland in Canada 10 years following restoration (Strack and Zuback, 2013). Similarly, the C balance of BP ( $\left.268 \mathrm{~g} \mathrm{C} \mathrm{m}^{-2} \mathrm{yr}^{-1}\right)$ in our study was about half of the $547 \mathrm{~g} \mathrm{C} \mathrm{m}^{-2} \mathrm{yr}^{-1}$ emitted at the Canadian unrestored site. However, high emissions in the study of Strack and Zuback (2013) were partly attributed to the dry conditions during the study year. This indicates that restored peatlands are unlikely to provide an annual $\mathrm{C}$ sink during the first decade following restoration of peat extraction sites. However, compared to naturally re-vegetating peatlands, which may require $20-50$ years to reach a neutral or negative $\mathrm{C}$ balance (Bortoluzzi et al., 2006; Yli-Petäys et al., 2007; Samaritani et al., 2011), initiating the restoration by rewetting in combination with re-introduction of peatland vegetation might reduce the time required for the ecosystem to return to being a $\mathrm{C}$ sink similar to that of a natural peatland (Tuittila et al., 2004; Roulet et al., 2007; Nilsson et al., 2008).

The similar GHG balances in the two restored treatments $\operatorname{Res}_{H}$ and Res ${ }_{L}$ suggest that the differences in the mean WTL had a limited effect on the GHG balance within the few years following restoration of the peat extraction area. Moreover, the GHG balances in the restored treatments were driven primarily by the NEE, while the contribution of $\mathrm{CH}_{4}$ and $\mathrm{N}_{2} \mathrm{O}$ exchanges remained minor in our study. In contrast, 30 years after rewetting of a German bog, high $\mathrm{CH}_{4}$ emission were reported as the main component of the GHG balance (Vanselow-Algan et al., 2015). The same study also reported GHG balances ranging from 25 to $53 \mathrm{tCO}_{2} \mathrm{eqha}^{-1} \mathrm{yr}^{-1}$ which are considerably higher compared to our study. This indicates that the GHG balances of restored peatlands may vary greatly over longer time spans. Moreover, this also suggests the GHG balance of peatland restoration with differing WTL baselines is likely to further diverge over time due to contrasting trajectories in vegetation development and changes in soil biogeochemistry (e.g., pH, nutrient contents and soil moisture dynamics).

While the two restored treatments had similar GHG balances, the difference between the GHG balances in restored and BP treatments was considerable. Only 3 years following restoration, the GHG balance in the restored treatments was reduced to about half of that in BP. This reduction was mainly due to lower annual $\mathrm{CO}_{2}$ emissions (i.e., lower NEE) in the restored treatments compared to BP likely as a result of increased WTL and vegetation development. In addition, annual $\mathrm{N}_{2} \mathrm{O}$ emissions were also significantly reduced in the restored treatments, although, compared to the differences in the $\mathrm{CO}_{2}$ balance, the impact of the reduction in $\mathrm{N}_{2} \mathrm{O}$ emis- sions on the GHG balance was relatively small. Overall, our study suggests that peatland restoration may provide an effective method to mitigate the negative climate impacts of abandoned peat extraction areas in the short term. However, due to the lack of long-term observations and recent reports of potential high $\mathrm{CH}_{4}$ emissions occurring several decades after rewetting (Yli-Petäys et al., 2007; Vanselow-Algan et al., 2015), it remains uncertain whether restoration of abandoned peat extraction areas may also provide an after-use solution with climate mitigation potential in the long term.

\section{Conclusions}

We found that differences in the re-established WTL strongly affected the vegetation communities following restoration of the abandoned peat extraction area. Furthermore, the difference in vegetation cover and composition was identified as the main control of within- and between-site variations in GPP, NPP and $R_{\mathrm{a}}$. We therefore conclude that variations in WTL baselines may have important implications for plantrelated $\mathrm{CO}_{2}$ fluxes in restored peatlands. In contrast, differences in the WTL baseline had only small effects on NEE due to the concurrent changes in plant production and respiration in the wetter and drier restoration treatments. Moreover, since $\mathrm{CH}_{4}$ and $\mathrm{N}_{2} \mathrm{O}$ exchanges were also similar in the two restored treatments, this study suggests that differing mean WTLs had a limited impact on the C and GHG balances 3 years following restoration. Furthermore, we observed a considerable reduction of $R_{\mathrm{h}}$ in the restored treatments which advocates rewetting as an effective method to reduce aerobic organic matter decomposition in drained peatlands. In contrast, our study suggests that the effects of rewetting on $\mathrm{CH}_{4}$ fluxes were negligible 3 years following restoration. However, rewetting reduced the $\mathrm{N}_{2} \mathrm{O}$ emissions by the order of 1-2 magnitudes which indicates a high potential of peatland restoration in reducing the $\mathrm{N}_{2} \mathrm{O}$ emissions commonly occurring in drained peatlands. Three years following restoration, the $\mathrm{C}$ and GHG balances of the restored treatments were reduced by approximately half relative to those of the abandoned bare peat area. We therefore conclude that peatland restoration may effectively mitigate the negative climate impacts of abandoned peat extraction areas; however, longer time spans may be needed to return these sites into net $\mathrm{C}$ sinks.

Acknowledgements. This study was supported by the European Regional Development Fund (Centre of Excellence in Environmental Adaptation ENVIRON and Centre of Excellence in Biodiversity Research FIBIR), by the Ministry of Education and Research of the Republic of Estonia (grants IUT2-16, IUT34-7 and IUT34-9) and by the Estonian Environmental Observatory Biosphere-Atmosphere Science and Development Programme: BioAtmos (KESTA, SLOOM12022T). We would like to thank Eeva-Stiina Tuittila for her valuable comments on the original 
manuscript version.

Edited by: R. Conant

\section{References}

Basiliko, N., Knowles, R., and Moore, T. R.: Roles of moss species and habitat in methane consumption potential in a northern peatland, Wetlands, 24, 178-185, doi:10.1672/02775212(2004)024[0178:ROMSAH]2.0.CO;2, 2004.

Basiliko, N., Blodau, C., Roehm, C., Bengtson, P., and Moore, T. R.: Regulation of Decomposition and Methane Dynamics across Natural, Commercially Mined, and Restored Northern Peatlands, Ecosystems, 10, 1148-1165, 2007.

Bortoluzzi, E., Epron, D., Siegenthaler, A., Gilbert, D., and Buttler, A.: Carbon balance of a European mountain bog at contrasting stages of regeneration, New Phytol., 172, 708-718, doi:10.1111/j.1469-8137.2006.01859.x, 2006.

Bubier, J., Crill, P., Mosedale, A., Frolking, S., and Linder, E.: Peatland responses to varying interannual moisture conditions as measured by automatic $\mathrm{CO}_{2}$ chambers, Global Biogeochem. $\mathrm{Cy}$., 17, 1066, doi:10.1029/2002GB001946, 2003.

Bubier, J. L.: The Relationship of Vegetation to Methane Emission and Hydrochemical Gradients in Northern Peatlands, J. Ecol., 83, 403-420, doi:10.2307/2261594, 1995.

Charman, D. J., Beilman, D. W., Blaauw, M., Booth, R. K., Brewer, S., Chambers, F. M., Christen, J. A., Gallego-Sala, A., Harrison, S. P., Hughes, P. D. M., Jackson, S. T., Korhola, A., Mauquoy, D., Mitchell, F. J. G., Prentice, I. C., van der Linden, M., De Vleeschouwer, F., Yu, Z. C., Alm, J., Bauer, I. E., Corish, Y. M. C., Garneau, M., Hohl, V., Huang, Y., Karofeld, E., Le Roux, G., Loisel, J., Moschen, R., Nichols, J. E., Nieminen, T. M., MacDonald, G. M., Phadtare, N. R., Rausch, N., Sillasoo, Ü., Swindles, G. T., Tuittila, E.-S., Ukonmaanaho, L., Väliranta, M., van Bellen, S., van Geel, B., Vitt, D. H., and Zhao, Y.: Climaterelated changes in peatland carbon accumulation during the last millennium, Biogeosciences, 10, 929-944, doi:10.5194/bg-10929-2013, 2013.

Clymo, R.: Peat, in: Ecosystems of the world, vol. 4A, Mires: swamp, bog, fen and moor, edited by: Gore, A. J. P., Elsevier, Amsterdam, 159-224, 1983.

Ferland, C. and Rochefort, L.: Restoration techniques for Sphagnum-dominated peatlands, Can. J. Botany, 75, 1110-1118, doi:10.1139/b97-122, 1997.

Firestone, M. and Davidson, E.: Microbiological Basis of NO and $\mathrm{N}_{2} \mathrm{O}$ Production and Consumption in Soil, edited by: Andreae, M. and Schimel, D., John Wiley \& Sons Ltd, Chichester, 1989.

Frenzel, P. and Karofeld, E.: $\mathrm{CH}_{4}$ emission from a hollowridge complex in a raised bog: The role of $\mathrm{CH}_{4}$ production and oxidation, Biogeochemistry, 51, 91-112, doi:10.1023/A:1006351118347, 2000.

Frolking, S., Roulet, N. T., Moore, T. R., Richard, P. J. H., Lavoie, M., and Muller, S. D.: Modeling Northern Peatland Decomposition and Peat Accumulation, Ecosystems, 4, 479-498, doi:10.1007/s10021-001-0105-1, 2001.

Gorham, E.: Northern Peatlands: Role in the Carbon Cycle and Probable Responses to Climatic Warming, Ecol. Appl., 1, 182195, doi:10.2307/1941811, 1991.
Graf, M. and Rochefort, L.: Examining the Peat-Accumulating Potential of Fen Vegetation in the Context of Fen Restoration of Harvested Peatlands, Ecoscience, 16, 158-166, doi:10.2980/162-3128, 2009.

IPCC: The Physical Science Basis, Contribution of Working Group I to the Fifth Assessment Report of the Intergovernmental Panel on Climate Change, edited by: Stocker, T. F., Qin, D., Plattner, G.-K., Tignor, M., Allen, S. K., Boschung, J., Nauels, A., Xia, Y., Bex, V., and Midgley, P. M., Cambridge University Press, Cambridge, 2013.

Joosten, H. and Clarke, D.: Wise use of mires and peatlands: background and principles including a framework for decisionmaking, International Mire Conservation Group and Internatonal Peat Society, 304 pp., 2002.

Karofeld, E., Müür, M., and Vellak, K.: Factors affecting revegetation dynamics of experimentally restored extracted peatland in Estonia, Environ. Sci. Pollut. Res., doi:10.1007/s11356015-5396-4, in press, 2015.

Klemedtsson, L., Von Arnold, K., Weslien, P., and Gundersen, P.: Soil $\mathrm{CN}$ ratio as a scalar parameter to predict nitrous oxide emissions, Glob. Change Biol., 11, 1142-1147, doi:10.1111/j.13652486.2005.00973.x, 2005.

Lai, D. Y. F.: Methane Dynamics in Northern Peatlands: A Review, Pedosphere, 19, 409-421, 2009.

Lamers, L. P. M., Vile, M. A., Grootjans, A. P., Acreman, M. C., van Diggelen, R., Evans, M. G., Richardson, C. J., Rochefort, L., Kooijman, A. M., Roelofs, J. G. M., and Smolders, A. J. P.: Ecological restoration of rich fens in Europe and North America: from trial and error to an evidence-based approach, Biol. Rev. Camb. Philos., 90, 182-203, doi:10.1111/brv.12102, 2015.

Larmola, T., Tuittila, E.-S., Tiirola, M., Nykänen, H., Martikainen, P. J., Yrjälä, K., Tuomivirta, T., and Fritze, H.: The role of Sphagnum mosses in the methane cycling of a boreal mire, Ecology, 91, 2356-2365, doi:10.1890/09-1343.1, 2010.

Loftfield, N., Flessa, H., Augustin, J., and Beese, F.: Automated Gas Chromatographic System for Rapid Analysis of the Atmospheric Trace Gases Methane, Carbon Dioxide, and Nitrous Oxide, J. Environ. Qual., 26, 560-564, doi:10.2134/jeq1997.00472425002600020030x, 1997.

Maljanen, M., Sigurdsson, B. D., Guðmundsson, J., Óskarsson, H., Huttunen, J. T., and Martikainen, P. J.: Greenhouse gas balances of managed peatlands in the Nordic countries - present knowledge and gaps, Biogeosciences, 7, 2711-2738, doi:10.5194/bg7-2711-2010, 2010.

Martikainen, P. J., Nykänen, H., Crill, P., and Silvola, J.: Effect of a lowered water table on nitrous oxide fluxes from northern peatlands, Nature, 366, 51-53, doi:10.1038/366051a0, 1993.

McNeil, P. and Waddington, J. M.: Moisture controls on Sphagnum growth and $\mathrm{CO}_{2}$ exchange on a cutover bog, J. Appl. Ecol., 40, 354-367, doi:10.1046/j.1365-2664.2003.00790.x, 2003.

Moore, T. R. and Dalva, M.: The influence of temperature and water table position on carbon dioxide and methane emissions from laboratory columns of peatland soils, J. Soil Sci., 44, 651-664, doi:10.1111/j.1365-2389.1993.tb02330.x, 1993.

Nilsson, M., Sagerfors, J., Buffam, I., Laudon, H., Eriksson, T., Grelle, A., Klemedtsson, L., Weslien, P., and Lindroth, A.: Contemporary carbon accumulation in a boreal oligotrophic minerogenic mire - a significant sink after accounting for all C- 
fluxes, Glob. Change Biol., 14, 2317-2332, doi:10.1111/j.13652486.2008.01654.x, 2008.

Pouliot, R., Rochefort, L., and Karofeld, E.: Initiation of microtopography in re-vegetated cutover peatlands: evolution of plant species composition, Appl. Veg. Sci., 15, 369-382, doi:10.1111/j.1654-109X.2011.01164.x, 2012.

Quinty, F. and Rochefort, L.: Peatland Resoration Guide, Second Edn., Canadian Sphagnum Peat Moss Association and New Brunswick Department of Natural Resources and Energy, 2003.

Regina, K., Nykänen, H., Silvola, J., and Martikainen, P. J.: Fluxes of nitrous oxide from boreal peatlands as affected by peatland type, water table level and nitrification capacity, Biogeochemistry, 35, 401-418, doi:10.1007/BF02183033, 1996.

Riutta, T., Laine, J., and Tuittila, E.-S.: Sensitivity of $\mathrm{CO}_{2}$ Exchange of Fen Ecosystem Components to Water Level Variation, Ecosystems, 10, 718-733, doi:10.1007/s10021-007-9046-7, 2007a.

Riutta, T., Laine, J., Aurela, M., Rinne, J., Vesala, T., Laurila, T., Haapanala, S., Pihlatie, M., and Tuittila, E.-S.: Spatial variation in plant community functions regulates carbon gas dynamics in a boreal fen ecosystem, Tellus B, 59, 838-852, doi:10.3402/tellusb.v59i5.17063, 2007b.

Rochefort, L. and Lode, E.: Restoration of Degraded Boreal Peatlands, in: Boreal Peatland Ecosystems, edited by: Wieder, K. and Vitt, D., Springer, Berlin, Heidelberg, 381-423, 2006.

Roobroeck, D., Butterbach-Bahl, K., Brüggemann, N., and Boeckx, P.: Dinitrogen and nitrous oxide exchanges from an undrained monolith fen: short-term responses following nitrate addition, Eur. J. Soil Sci., 61, 662-670, doi:10.1111/j.13652389.2010.01269.x, 2010.

Roulet, N. T., Lafleur, P. M., Richard, P. J. H., Moore, T. R., Humphreys, E. R., and Bubier, J.: Contemporary carbon balance and late Holocene carbon accumulation in a northern peatland, Glob. Change Biol., 13, 397-411, doi:10.1111/j.13652486.2006.01292.x, 2007.

Rydin, H.: Effect of Water Level on Desiccation of Sphagnum in Relation to Surrounding Sphagna, Oikos, 45, 374-379, doi:10.2307/3565573, 1985.

Saarnio, S., Wittenmayer, L., and Merbach, W.: Rhizospheric exudation of Eriophorum vaginatum L. - Potential link to methanogenesis, Plant Soil, 267, 343-355, doi:10.1007/s11104-0050140-3, 2004.

Samaritani, E., Siegenthaler, A., Yli-Petäys, M., Buttler, A., Christin, P.-A., and Mitchell, E. A. D.: Seasonal Net Ecosystem Carbon Exchange of a Regenerating Cutaway Bog: How Long Does it Take to Restore the C-Sequestration Function?, Restor. Ecol., 19, 480-489, doi:10.1111/j.1526-100X.2010.00662.x, 2011.

Schulze, E., Kelliher, F. M., Korner, C., Lloyd, J., and Leuning, R.: Relationships among Maximum Stomatal Conductance, Ecosystem Surface Conductance, Carbon Assimilation Rate, and Plant Nitrogen Nutrition: A Global Ecology Scaling Exercise, Annu. Rev. Ecol. Syst., 25, 629-662, doi:10.1146/annurev.es.25.110194.003213, 1994.

Silvan, N., Tuittila, E.-S., Kitunen, V., Vasander, H., and Laine, J.: Nitrate uptake by Eriophorum vaginatum controls $\mathrm{N}_{2} \mathrm{O}$ production in a restored peatland, Soil Biol. Biochem., 37, 1519-1526, doi:10.1016/j.soilbio.2005.01.006, 2005.

Silvola, J., Alm, J., Ahlholm, U., Nykanen, H., and Martikainen, P. J.: $\mathrm{CO}_{2}$ fluxes from peat in boreal mires under varying temperature and moisture conditions, J. Ecol., 84, 219-228, doi:10.2307/2261357, 1996.

Strack, M. and Zuback, Y. C. A.: Annual carbon balance of a peatland $10 \mathrm{yr}$ following restoration, Biogeosciences, 10, 2885-2896, doi:10.5194/bg-10-2885-2013, 2013.

Strack, M., Keith, A. M., and Xu, B.: Growing season carbon dioxide and methane exchange at a restored peatland on the Western Boreal Plain, Ecol. Eng., 64, 231-239, doi:10.1016/j.ecoleng.2013.12.013, 2014.

Ström, L., Mastepanov, M., and Christensen, T. R.: Speciesspecific Effects of Vascular Plants on Carbon Turnover and Methane Emissions from Wetlands, Biogeochemistry, 75, 65-82, doi:10.1007/s10533-004-6124-1, 2005.

Thomas, K. L., Benstead, J., Davies, K. L., and Lloyd, D.: Role of wetland plants in the diurnal control of $\mathrm{CH}_{4}$ and $\mathrm{CO}_{2}$ fluxes in peat, Soil Biol. Biochem., 28, 17-23, doi:10.1016/00380717(95)00103-4, 1996.

Tuittila, E.-S., Komulainen, V.-M., Vasander, H., and Laine, J.: Restored cut-away peatland as a sink for atmospheric $\mathrm{CO}_{2}$, Oecologia, 120, 563-574, doi:10.1007/s004420050891, 1999.

Tuittila, E.-S., Komulainen, V.-M., Vasander, H., Nykänen, H., Martikainen, P. J., and Laine, J.: Methane dynamics of a restored cut-away peatland, Glob. Change Biol., 6, 569-581, doi:10.1046/j.1365-2486.2000.00341.x, 2000a.

Tuittila, E.-S., Rita, H., Vasander, H., and Laine, J.: Vegetation patterns around Eriophorum vaginatum L. tussocks in a cutaway peatland in southern Finland, Can. J. Botany, 78, 47-58, doi:10.1139/b99-159, 2000b.

Tuittila, E. S., Vasander, H., and Laine, J.: Sensitivity of C sequestration in reintroduced Sphagnum to water-level variation in a cutaway peatland, Restor. Ecol., 12, 483-493, doi:10.1111/j.1061-2971.2004.00280.x, 2004.

Turner, N. C., Schulze, E.-D., and Gollan, T.: The responses of stomata and leaf gas exchange to vapour pressure deficits and soil water content, Oecologia, 65, 348-355, doi:10.1007/BF00378908, 1985.

Turunen, J., Tomppo, E., Tolonen, K., and Reinikainen, A.: Estimating carbon accumulation rates of undrained mires in Finlandapplication to boreal and subarctic regions, The Holocene, 12, 69-80, doi:10.1191/0959683602hl522rp, 2002.

Vanselow-Algan, M., Schmidt, S. R., Greven, M., Fiencke, C., Kutzbach, L., and Pfeiffer, E.-M.: High methane emissions dominated annual greenhouse gas balances 30 years after bog rewetting, Biogeosciences, 12, 4361-4371, doi:10.5194/bg-12-4361$2015,2015$.

Vasander, H., Tuittila, E.-S., Lode, E., Lundin, L., Ilomets, M., Sallantaus, T., Heikkilä, R., Pitkänen, M.-L., and Laine, J.: Status and restoration of peatlands in northern Europe, Wetl. Ecol Manag., 11, 51-63, doi:10.1023/A:1022061622602, 2003.

Vitt, D. H., Halsey, L. A., Bauer, I. E., and Campbell, C.: Spatial and temporal trends in carbon storage of peatlands of continental western Canada through the Holocene, Can. J. Earth Sci., 37, 683-693, doi:10.1139/e99-097, 2000.

Waddington, J. M. and Day, S. M.: Methane emissions from a peatland following restoration, J. Geophys. Res.-Biogeo., 112, G03018, doi:10.1029/2007JG000400, 2007.

Waddington, J. M. and Warner, K. D.: Atmospheric $\mathrm{CO}_{2}$ sequestration in restored mined peatlands, Ecoscience, 8, 359-368, 2001. 
Waddington, J. M., Strack, M., and Greenwood, M. J.: Toward restoring the net carbon sink function of degraded peatlands: Short-term response in $\mathrm{CO}_{2}$ exchange to ecosystemscale restoration, J. Geophys. Res.-Biogeo., 115, G01008, doi:10.1029/2009JG001090, 2010.

Weltzin, J. F., Pastor, J., Harth, C., Bridgham, S. D., Updegraff, K., and Chapin, C. T.: Response of bog and fen plant communities to warming and water-table manipulations, Ecology, 81, 3464-3478, doi:10.1890/00129658(2000)081[3464:ROBAFP]2.0.CO;2, 2000.
Whiting, G. J. and Chanton, J. P.: Greenhouse carbon balance of wetlands: methane emission versus carbon sequestration, Tellus B, 53, 521-528, doi:10.3402/tellusb.v53i5.16628, 2001.

Windsor, J., Moore, T. R., and Roulet, N. T.: Episodic fluxes of methane from subarctic fens, Can. J. Soil Sci., 72, 441-452, doi:10.4141/cjss92-037, 1992.

Yli-Petäys, M., Laine, J., Vasander, H., and Tuittila, E.-S.: Carbon gas exchange of a re-vegetated cut-away peatland five decades after abandonment, Boreal Environ. Res., 12, 177-190, 2007. 